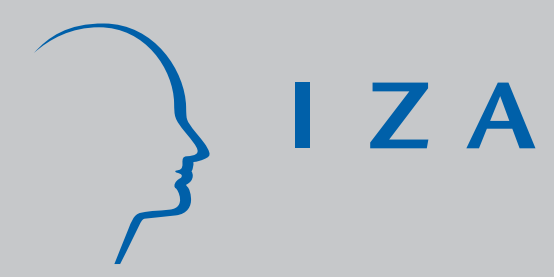

IZA DP No. 3770

Motivating Altruism: A Field Study

Nicola Lacetera

Mario Macis

October 2008 


\title{
Motivating Altruism: A Field Study
}

\author{
Nicola Lacetera \\ Case Western Reserve University \\ Mario Macis \\ University of Michigan \\ and IZA
}

\section{Discussion Paper No. 3770 \\ October 2008}

\author{
IZA \\ P.O. Box 7240 \\ 53072 Bonn \\ Germany \\ Phone: +49-228-3894-0 \\ Fax: +49-228-3894-180 \\ E-mail: iza@iza.org
}

Any opinions expressed here are those of the author(s) and not those of IZA. Research published in this series may include views on policy, but the institute itself takes no institutional policy positions.

The Institute for the Study of Labor (IZA) in Bonn is a local and virtual international research center and a place of communication between science, politics and business. IZA is an independent nonprofit organization supported by Deutsche Post World Net. The center is associated with the University of Bonn and offers a stimulating research environment through its international network, workshops and conferences, data service, project support, research visits and doctoral program. IZA engages in (i) original and internationally competitive research in all fields of labor economics, (ii) development of policy concepts, and (iii) dissemination of research results and concepts to the interested public.

IZA Discussion Papers often represent preliminary work and are circulated to encourage discussion. Citation of such a paper should account for its provisional character. A revised version may be available directly from the author. 


\section{ABSTRACT}

\section{Motivating Altruism: A Field Study*}

This paper analyzes the effects of a legislative provision that grants a one-day paid leave of absence to blood donors who are employees in Italy. The analysis is based on a unique dataset with the complete donation histories of the blood donors in an Italian town. The cross-sectional variation in job market status and type of employers, and job switching over time by a subset of donors, are the sources of variation we employ to study whether donors are responsive to the paid-day-off incentive in the choice of their donation days, and in the frequency of their donations. Our results indicate that economic considerations do affect blood donation decisions, for donors donate in days of the week that, given the day-off benefit, maximize their material returns in terms of consecutive days off work. We also find evidence, however, consistent with heterogeneous motivations in different donors, since a subset of donors systematically do not take advantage of the material reward. Finally, we find that the day-off privilege leads donors who are employees to make, on average, one extra donation per year. We discuss the implications of our findings for policies aimed at increasing the supply of blood, and more generally for incentivizing pro-social behavior.

JEL Classification: D12, D64, I18

Keywords: incentives, altruism, public good provision, pro-social behavior, public health

Corresponding author:

Mario Macis

Department of Business Economics and Public Policy

Ross School of Business

University of Michigan

701 Tappan St, ER3602

Ann Arbor, MI 48109-1234

USA

E-mail: mmacis@bus.umich.edu

\footnotetext{
"We thank Oriana Bandiera, Gary Becker, Alberto Bisin, Thomas Buchmueller, Christopher Carpenter, David Clingingsmith, Stefano DellaVigna, John DiNardo, Luigi Guiso, Daniel Hamermesh, Uri Gneezy, Antonio Lacetera, Francesca Mazzolari, Hugo Mialon, Felix Oberholzer-Gee, Emily Oster, James Rebitzer, Heather Royer, Ariel Rubinstein, Jesse Shapiro, Joel Slemrod, Justin Sydnor, Lorenzo Zirulia, Ezra Zuckerman, and seminar participants at Indiana University, Northwestern University, MIT, UC Irvine, the University of Michigan, Cleveland State University, Case Western Reserve University, the University of Chicago, the 2008 ASSA Meetings and the 2008 ASHE Conference for very useful comments. We are extremely thankful to the President, Board, members, and staff of The Town's unit of the Italian Association of Blood Donors (Associazione Volontari Italiani del Sangue, AVIS), and to the Head and staff of the Transfusion Unit in The Town's Hospital, for their precious collaboration. Raffaella Manna has offered an invaluable contribution to the data collection effort, and Hong Pum Chung has provided excellent research assistance. Financial support from the Ross School of Business Small Grants Research Fund is gratefully acknowledged.
} 


\section{Introduction}

Studying the relationship between economic incentives and pro-social behavior carries major economic and social consequences. Pro-social activities represent a substantial part of social life, including actions with immediate as well as long-term benefits such as donating money for a cause or an organization, volunteering for a party during election times, cleaning beaches, or donating blood. Millions of people, every year, dedicate time, effort, and financial resources to voluntary, pro-social activities. Over sixty million Americans, for example, have undertaken volunteer activities in 2006 (BLS, 2007), and the total value of volunteer time in the US is estimated to be over $\$ 240$ billion (Independent Sector, 2006). In recent years, moreover, a number of scholars have argued that pro-social activities represent an important manifestation of a country's social capital which, together with other immaterial characteristics such as trust, culture and religion, appears to contribute explain a country's long-run economic prosperity and growth. ${ }^{1}$

In this paper, we study how material incentives influence a particularly relevant pro-social activity: blood donations. Blood transfusions are required in such critical situations as massive blood loss due to trauma, blood replacement during surgical interventions, and the treatment of premature babies, as well as to treat several chronic diseases. ${ }^{2}$ In recent years, the demand for blood has increased dramatically, due, among other causes, to population aging and to new medical and surgical procedures, such as organ transplants (DiRado 2004, www.bloodbook.com). Blood supply is not keeping up with demand, however, and situations of shortage are the rule rather than the exception in most Western countries, and even more so in developing nations. ${ }^{3}$ Neither eligibility criteria, nor a lack of information seem to explain why this supply shortage is occurring, since, for example, only 1/8th of eligible Americans (40\% of the population) donate, and information campaigns, as well as communications about shortage periods (for example during the summer season and around the holidays), are conducted with high frequency. An alternative cause left to be explored concerns people's behaviors and incentives. Individuals might simply find it not worthwhile to dedicate time to blood donation if the benefits of donating blood fall short of the opportunity costs. This implies that explicit incentives might play a role in stimulating donations, which are, in most countries, based on voluntary, unpaid contribution.

The question of whether extrinsic incentives help or hinder the propensity to donate blood and more generally the performance of altruistic activities, however, is theoretically ambiguous and empirically unsettled. Standard economic theory would predict that, with the addition of a new set of incentives for the performance of a given activity, agents should increase the supply of that

\footnotetext{
${ }^{1}$ See, for example, Guiso, Sapienza and Zingales (2006), McCleary and Barro (2006), and Tabellini (2008).

${ }^{2}$ There is no available substitute for human blood, therefore all blood needed must be supplied by individuals. Synthetic blood substitutes are at a very early stage of development and still a long way before they can replace real blood in routine transfusions (Squires 2002, HemoBiotech 2008).

${ }^{3}$ In the US, the American Red Cross and other organizations collecting blood need to have, at each point in time, the blood necessary for three days of demand at each location and for each blood type, but this target is seldom met, especially for rare blood types. Moreover, it is estimated that worldwide, there is currently a shortage of about 22 million units of blood (HemoBiotech 2008).
} 
activity. Or, if the performance of that particular activity is not responsive to the new set of incentives, its supply should just not change (Solow 1971, Arrow 1972). A few recent theoretical works, however, argue that extrinsic incentives, and especially those of economic or monetary nature, might crowd out the quantity and quality of the supplied altruistic activity. Benabou and Tirole (2006), in particular, build a model where individuals perform altruistic activities to increase their social reputation and self-respect. The introduction of economic rewards creates doubts about the true reason behind pro-social behavior, thus potentially crowding out intrinsic motives. Economic incentives, therefore, can backfire instead of adding up to altruistic motivations. These findings formalize the early claims of Titmuss (1971) about the negative effects of paying for blood, in terms of both lower quality of blood, and lower quantity since people would refrain from a prosocial activity if it is paid. Titmuss' 1971 book The Gift Relationship, in fact, was very influential in marking the end of a paid blood supply system in the US in the 1970s (Healy 2006, Shearmur 2007).

As for empirical studies, early experiments by Edward Deci and his collaborators found that adding explicit rewards for the performance of activities which are originally motivated by intrinsic reasons leads to a reduction in the performance of those activities (Deci 1975). More recently, similar findings have been obtained by, among others, Frey and Oberholzer-Gee (1997) and Gneezy and Rustichini (2000). Gneezy and Rustichini, however, find that "large enough" incentives do stimulate pro-social behavior. With specific reference to blood donation, Mellstrom and Johannesson (2008) find that Swedish female college students are less willing to undertake a health test in order to be able to donate blood afterward, if they are offered monetary incentives. The authors interpret their results as consistent with the claims of Titmuss (1971), although no crowding-out was detected among males. In partial contrast to these results, Goette and Stutzer (2008) conduct a large field experiment in Switzerland and find that offering lottery tickets to promote donations increased turnout at the blood drives. In sum, the evidence on whether material incentives play a positive role in attracting donors, just like they motivate other activities (Dionne and Vanasse 1997, Lazear 2000, Lach and Schankermann 2008) is mixed. ${ }^{4}$

We contribute to this literature by investigating the effects of an explicit economic incentive granted to Italian blood donors: the right to a paid day off work on the same day they donate blood or blood components, introduced by Law 584 of 1967. The law applies to all donors who are employed at any private or public organization, and salary and contributions are reimbursed by the state. Our analysis is based on a unique, hand-collected, longitudinal dataset comprising the whole individual histories of blood donations of the entire population of donors in an Italian mid-sized

\footnotetext{
${ }^{4} \mathrm{~A}$ number of studies have focused on other types of extrinsic motives, namely the quest for social recognition through the performance of altruistic activities. Theoretical models, anecdotal evidence, and laboratory experiments suggest that, in fact, individuals' altruistic behavior is also driven by social-image concerns. See for example Harbaugh (1998a, 1998b), Wedekind (1998), Nowak and Sigmund (2000), Price (2003), Ariely, Bracha and Meier (forthcoming), Polborn (2007) and Lacetera and Macis (2008a). On the whole debate on the determinants of pro-social behavior, see the comprehensive survey by Meier (2006).
} 
town (The Town) in the periods 1985-89 and 2002-06. ${ }^{5}$ In addition to demographic information and the number and dates of donations made by about 3,000 unique donors, the database includes information on the donors' labor market status and occupation, as well as the identity of the employers for those donors who are employees.

We first exploit the cross-sectional variation in job market status and type of employers, and the different economic benefits associated with donating in different days of the week to test for whether donors are responsive to economic considerations in a way that is consistent with standard economic theory. Only those donors who are employees can benefit from the day-off privilege. In addition, since donations can be made only in the morning, Monday through Saturday, and most donors-employees do not work on Saturdays, donating on different days of the week carries different economic advantages. Donating on Fridays, in particular, potentially leads to the highest material benefit if an employee is free on Saturdays, since the donor-employee has, in fact, 2.5 consecutive days off available after the donation. Donating on Mondays (or on Saturdays for those workers who do not have Saturdays off) leads to having only two (or one and a half) full consecutive days off. Any other day of the week allows for only one, isolated day off, and finally, for those workers who have Saturday off by contract (this being the case for the vast majority of Italian workers), a Saturday donation does not bring any material benefit. Our findings indicate that donors do respond to the economic value associated to donating in different days in a way that is consistent with standard economic intuition. Donors-employees are significantly more likely to donate on Friday and (less strongly) on Monday compared to individuals out of the labor force. The latter group of donors, instead, not being affected by the possibility of a day off, tend to distribute their donations uniformly during the week. Employers and self-employed individuals, who also do not benefit from the policy, tend to cluster their donations in those days in which they do not work: Store owners disproportionately donate on Mondays, when stores in The Town are, by law, closed; and other self-employed donors donate on Saturdays, when their businesses do not operate.

Economic considerations appear therefore as predominant over such concerns as sending a "bad signal" about one's generosity to the community by donating when material rewards are highest. Our results are even stronger when we focus on individuals employed in large firms, which corroborates our interpretation of the findings. In fact, not only are workers in large firms less "indispensable," therefore bearing a lower cost from leaving work during a business day, but unlike workers in small firms, they are also heavily protected by strict firing restrictions, and therefore they should be much less concerned about taking days off compared to workers in small firms.

We also find evidence suggesting that the motives that guide altruistic actions are heterogeneous in the population. In fact, a substantial share of the population of donors-employees donates on Saturdays, when the additional, explicit incentive is not present. In addition, donors-employees who donate more frequently on Fridays (Saturdays) only rarely donate on Saturdays (Fridays).

\footnotetext{
${ }^{5}$ To protect the privacy of the donors in our database, we have agreed to keep the name of The Town (as well as any other identifying information) confidential.
} 
Therefore, there is a subset of donors who appear to perform pro-social activities for reasons orthogonal to, or possibly colliding with, explicit incentives. The stability of behavior of individual donors over time, which we are able to document thanks to the longitudinal nature of our data, indicates the presence of different "types" of contributors, consistent with the framework of Benabou and Tirole (2006) and with similar findings on the response to high-powered incentives in the workplace (Nagin, Rebitzer, Taylor, and Sanders, 2002).

Finally, we use the longitudinal nature of our data, i.e., the fact the we observe donors multiple times over the period of interest, and the fact that a subset of donors switch job status, to test whether the paid-day-off incentive induces donors who are employees to increase the number of donations. Fixed effects regressions comparing switchers to non-switchers reveal that donors who are employees increase their donation frequency by one donation a year. The effect appears to be symmetric, in that a reduction in donation frequency is detected for donors who cease to be employees. The evidence, therefore, is consistent with the paid-day-off provision stimulating more donations. Although our micro-level evidence is focused on the intensive margin, i.e. on the change in behavior of existing donors, aggregate evidence on the number of donors at the national level shows that, following the introduction of the day-off provision at the end of 1967, there was no reduction in the number of donors, which instead kept rising slightly above its previous trend. We can therefore conclude that removing this policy (a measure, in fact, recently advocated by the The Italian Employers' Association as well as by the Central Government) would likely result in a reduced number of donations.

In addition to providing novel findings from new sources of data, our study presents a number of methodological contributions with respect to the existing research on the impact of explicit incentives on the performance of altruistic activities. Most of the existing studies are laboratory experiments and analyze the intentions to perform some activities instead of their actual performance. Some scholars have expressed concerns about the external validity of laboratory experiments. Both existing lab and field experiments use "ad hoc" incentives, making it more likely for donors to suspect they are being observed. If potential donors infer they are being observed as a result of an unusual offer, then their behavior may be influenced not only by the incentive but also by the perception of being scrutinized (on these issues, see Harrison and List 2004, List 2006, Levitt and List 2007, and Lazear, Malmendier, and Weber, 2007). To the best of our knowledge, our study is the first to analyze the actual behavior of an entire population of blood donors in response to a naturally occurring incentive, therefore it serves as a useful complement to the experimental literature. In addition, the individuals in our field study are free not to enjoy the economic benefits by choosing the day of the week in which to donate, thus their choices are not constrained to a set of options defined by the experimenter. Many studies, moreover, use college students as subjects of laboratory and field experiments, and relatively gender-balanced samples. At least for the case of blood donations, individuals under the age of 25 represent only a small portion of the population 
of donors, and women are only one-quarter of the population of donors. ${ }^{6}$ Finally, existing studies rely only on cross-sectional data. By observing the same individuals multiple times, instead, we are able to account for individual heterogeneity, and we also can assess the presence of stable patterns of individual behavior and revealed preferences on material rewards for pro-social activities. In addition to being a substantive contribution, the identification of "types" of donors also reduces the possibility that our results are driven by "composition effects."

The remainder of the paper is structured as follows. Section 2 describes the data and the institutional context of this study. Section 3 illustrates the theoretical framework guiding our empirical analysis, and outlines our research design. Section 4 presents the empirical analysis and findings. Section 5 concludes with a summary of the findings and considerations on their welfare and policy implications. All tables and figures are gathered in the Appendixes.

\section{Data and institutional background}

The data used in this study originate from hand-collected information on the whole blood donation histories of all donors in an Italian town ("The Town" hereinafter) located in the Center-North part of the country. ${ }^{7}$ Before describing the data in detail, we report on the blood donation system in Italy and in The Town, since some features of the systems will be crucial for our empirical identification strategies.

\subsection{Blood donation in Italy and in The Town}

Blood donation in Italy is organized through blood banks, which are run by voluntary donor associations. These associations have a central headquarter as well as town-level units. In order to donate blood, an individual is required to become a member of one of these associations. The three major associations, which are present in different parts of the country and do not compete with one another, are Associazione Volontari Italiani del Sangue (AVIS), with about 1.1 million members in 2007, Federazione Italiana delle Associazioni Donatori di Sangue (FIDAS), with about 400,000 members (Caligaris 2007), and Fratres (150,000 members in 2000). ${ }^{8}$ Since the affiliation is to a local unit of the national associations, blood donors predominantly donate in the town where

\footnotetext{
${ }^{6}$ The average donor is about 40 years old in most Western countries, and only a minority of donors are younger than 25 .

${ }^{7}$ The demographic, social, and economic characteristics of The Town's population are highly representative of the overall Italian urban population. Statistics comparing the Town with other Italian towns under a number of socio-economic characteristics are available upon request.

${ }^{8}$ Blood donations run through blood banks and voluntary donor associations (which were present since the 1920s) have become the official blood donation and collection system in Italy, after a brief period, following the end of World War II, when the Red Cross played a prominent role. Similar blood bank systems exist in other countries, such as Denmark, Greece, Norway, Portugal, and Spain. In the UK, France, and Ireland, by contrast, the organization of blood donation is run by the State. The Red Cross, finally, is the dominant organization managing blood donation in such countries as Belgium, The Netherlands, Germany, and the US. In the US, however, the system is more heterogeneous and competitive, comprising the Red Cross, blood banks, and hospitals directly managing blood donations. See Healy (2006) on the different organizational modes of blood donations.
} 
"their" unit is located.

In The Town, blood donation is managed by the largest blood donor association, AVIS, and aphereses of either whole blood or blood's components (plasma, platelets) are performed at The Town's public hospital, Monday through Saturdays from 8 to 11 a.m. Donors do not make appointments, and they typically donate on a "first come, first served" basis.

The Italian law sets limits to the frequency of donations of blood and blood components. Whole blood can be collected once every 90 days from male donors and once every 180 days from females. Donors can give platelets once every 30 days and plasma once every 14 days. ${ }^{9}$ The time required for a platelet or plasma donation is about one hour, against an average of twenty minutes for a whole blood donation. Including the time to reach the donation site, the waiting time before the donation and the resting time at the hospital after the donation (which is higher for whole blood donation), on average a donor should expect a commitment of about two hours.

\subsection{The Data}

Using both AVIS' and The Town's hospital's archives, we identified all of the Association's members (and, therefore, all of The Town's blood donors) from 1985 to 2006, for whom we obtained the entire donation history over this 22-year period. Information on donors includes sex, age, blood type, and the date when each individual became a donor. Crucially for the aims of this paper, we have information, for a subset of donors, on their occupational status, job, and, in the case of employees, on their employers. AVIS does not update its members' occupational status on a regular (e.g., yearly) basis. Within our period of interest, updates were made in 1985 and 2002. We therefore limit our analysis to two subperiods, 1985 through 1989 and 2002 through 2006, attributing the same job status in the update years to the following four years. This introduces the possibility that for some donors and in some years occupation is recorded with error. Our results, however, do not change substantially when we restrict the analysis only to the years 1985 and $2002 .{ }^{10}$

Table 1 presents some basic descriptive statistics on our sample of donors. Over the years 1985-89 and 2002-06, 2,614 unique individuals have donated blood, 759 of whom were females. The number of active donors has increased steadily over time, going from 543 in 1985 to 1,282 in 2006, and so has the fraction of female donors, from 25 percent in the mid 1980s to about 29 percent in recent years. The pool of donors has also aged over time, moving from an average age of 38 to about 40 years. The vast majority of donors in The Town are repeat donors: The average number of donations per year is 2.4 donations per year, and the median number of donations over the

\footnotetext{
${ }^{9}$ Conversations with doctors and AVIS officials in The Town revealed that the type of donation is "exogenous" to a donor's choice. Donors, in general, join the Association to donate whole blood, and are assigned to donating blood components if they are not eligible to donate whole blood (e.g. if they have insufficient iron in their blood), or if there is some urgent need for a blood component. As a consequence, it is highly implausible that donors shift types of donations toward more "frequent ones" (e.g. shift from whole blood to platelets) as the awards thresholds approach.

${ }^{10}$ In addition, in the Italian labor market switching across broad occupational categories is limited, especially in the short run. For these reasons, we are confident that the error in reporting donors' labor market status is fairly limited.
} 
whole period of interest is 13 . Of the 826 donors active in the period 1985-89, 286 are still active in $2002-06 .^{11}$

[Table 1 about here]

Panel B of Table 1 displays the distribution of donors by labor market status. ${ }^{12}$ About $70 \%$ of male donors, in both time periods, are employees. In 1985-89, the only period for which information on the donors' employer is available, about 12 percent of donors-employees worked for a large employer - banks, companies offering public services such as utilities, and companies with a presence on a national level, which also operate in The Town. Self-employed and employers are relatively more numerous in more recent years (13 percent of male donors in 2002-06 against 10 percent in 1985-89), with a greater share of store owners over other types of non-salary workers. As for women, self-employed and employers represent only tiny fractions (and almost entirely composed of store owners), with salary workers and non-employed donors being predominant. A large majority of non-employed male donors are students. Among female non-employed donors, a sizable fraction is represented by housekeepers. ${ }^{13}$ Only a relatively small fraction of non-employed donors are retired or unemployed.

\subsection{An explicit incentive to blood donors: a one-day paid leave of absence}

According to the National Law 584 of 1967 (marginally amended in 1990), all donors who are employed at any private or public organization have the right to a paid day off work, on the same day they donate blood or blood components. Employers are refunded by the state for the related salary expenses they incur (including social security and other contributions). ${ }^{14}$ The stated objective of the law is to guarantee some rest to donors and to protect their health conditions. The provision is therefore equivalent to adding sick days to those an employee is entitled to by contract, with an important difference: Unlike an illness absence, when the employee is required to stay home (a medical inspector can be sent to check for the sickness claim), this requirement does not hold in the case of an absence for blood donation. ${ }^{15}$ To be able to claim the day off, donors must have a form signed by the doctor performing the apheresis. The Town's hospital, unfortunately, does not keep systematic records of which donors actually take the benefit up. From partial records as well

\footnotetext{
${ }^{11}$ Over 60 percent of male donors who were below the age of 40 in 1985 were still active in 2002 . In fact, reaching the age limit is what mostly explains why donors cease to donate and hence drop out of our database.

${ }^{12}$ Donors whose occupational status could not be determined because of the incompleteness of the AVIS records do not significantly differ from the rest of the donors in terms of age and other observable characteristics.

${ }^{13}$ The proportion of female donors who are housekeepers, however, declined from 27 percent in 1985-89 to about 15 percent in 2002-06, which reflects the increased labor force participation rates of Italian females in the past decades.

${ }^{14}$ Employees in other countries are typically allowed time during work hours to donate blood, usually without deductions in salary or accrued leave, but in the vast majority of cases these provisions just give donors the material time to make their donation, and in all cases the donor has to return to work after donating.

${ }^{15}$ Also similar to the rules regarding sick days is the absence of a formal requirement to inform the employer in advance of the intention to donate blood, and to not go to work, by an employee. The employer cannot refuse, in any case, to "concede" the one-day leave. This does not exclude that, on an informal basis, several employees give prior notice to their employers.
} 
as our conversations with the doctors and the hospital administrators, however, we gathered that take-up rates are quite high, especially during weekdays. Monday through Friday, four out of five donors-employees take the day off, and this fraction drops to less than two out of five on Saturdays (see Figure 7).

The typical work week of an employee is from Monday through Friday. Businesses, in particular, as well as most public workplaces, do not operate on Saturdays. Some exceptions are given by hospital doctors, whose work week typically includes some work over the weekend, teachers, since in Italian public schools (attended by the near totality of students) students have only Sundays off, and some employees in public workplaces such as City Hall clerks in offices open to the public. A further notable exception is given by stores, most of which are closed, by law, on Monday mornings and are open on Saturdays.

\section{Competing Hypotheses and Research Design}

\subsection{Theoretical framework}

As a framework to identify competing hypotheses on the impact of material incentives in the performance of pro-social activities, we outline a simplified version of the model proposed by Benabou and Tirole (2006) - BT thereafter. In BT, the utility that agents maximize, when performing a prosocial activity $a$, has the following form:

$$
U\left(a, y ; v_{a}, v_{y}, y, f\left(v_{a}, v_{y}\right), m_{a}, m_{y}\right)=v_{a} a+v_{y} y-c(a)+m_{a} E\left(v_{a} \mid a, y\right)-m_{y} E\left(v_{y} \mid a, y\right) .
$$

The pro-social activity $a$ can be thought of as a continuous, countable, or dichotomous $\{0,1\}$ variable. In the case of blood donation, a may represent the number of donations an agent decides to make over a certain period, or the decision to donate or not in, say, a given day or week. Each agent is of a $\left(v_{a}, v_{y}\right)$-type, where $v_{a}$ expresses the marginal intrinsic benefit from performing the pro-social activity, and $v_{y}$ represents the marginal extrinsic benefit from being given an additional, explicit reward $y$. The type is known only to the agent, while the joint distribution of $\left(v_{a}, v_{y}\right)$ is publicly known. The function $c(a)$ is the direct cost of performing $a$, while the term $r=$ $m_{a} E\left(v_{a} \mid a, y\right)-m_{y} E\left(v_{y} \mid a, y\right)$ represents the reputational concern: The individual might care about her positive social image as an altruist from performing $a$, and the negative social image as "greedy" from performing $a$ when explicit rewards are provided. The social-image effect is expressed in terms of the updated beliefs of the population of reference on the values of $v_{a}$ and $v_{y}$ for a given individual, and the parameters $m_{a}$ and $m_{y}$ determine the impact of these updated beliefs on the agent's utility. These parameters can be individual-specific as well. ${ }^{16}$

\footnotetext{
${ }^{16}$ In Benabou and Tirole (2006), an alternative intepretation of the social image component of the utility function is in terms of self-image concerns (see also Akerlof and Kranton, 2000). The BT model also considers the degree of visibility of the pro-social activity as affecting the social reputational concerns of the agent. In our basic framework we abstract from this visibility issue.
} 
The agent's problem can be seen as choosing the level of $a$, given the other variables. Alternatively, given the parameters, an established level of $a$ (e.g., donating blood once a year), and a menu of extrinsic rewards $Y$, the agent can be thought of as choosing between the different available rewards (see also Section IV of BT).

Within this model, the standard, rational-agent approach can be expressed by the assumption of both $m_{a}$ and $m_{y}$ being equal to zero. If this is the case, purely altruistic and purely "extrinsic" incentives would add to each other. Assuming that the direct cost function is well-behaved, an increase in the extrinsic incentive $y$ would never reduce the performance of the pro-social activity $a$. Or, if a menu of different levels of the explicit incentive $y$ is proposed for the performance of a fixed amount of $a$, the agent will choose the highest available reward. ${ }^{17}$

By contrast, the impact of an extrinsic reward can have ambiguous effects, once social or selfimage concerns are taken into consideration. On the one hand, the agent has an incentive to perform more of the altruistic act; on the other hand, the beliefs about her type are revised downward if she performs a high amount of the activity when explicit rewards are provided. The specific values of the parameters and the shape of the distribution will determine which effects would dominate for different values of the explicit reward $y$. We could have a negative relationship between extrinsic incentives and altruistic acts across the whole range of relevant values of $y$, or a positive relationship, or even a non-monotonic relationship. For example, the supply of the pro-social activity might be larger when no extra incentives are provided and when large explicit incentives are provided, and lower for intermediate values of $y$ (Gneezy and Rustichini 2000).

\subsection{Identifying the effects of the day-off provision}

Within a regime where a paid day off to employees is guaranteed, we identify a few sources of variation that change the economic incentives to donate blood, in different ways to different groups of donors. The first source of variation we exploit is simply given by the different days of the week, and the second main source of variation is given by the fact that the day-off provisions holds only for those donors who are employees, but not for, say, self-employed, business owners, and donors out of the labor force such as housekeepers, retired, students, as well as the unemployed. In addition, we use the fact that donations can be made, at the local hospital, Monday to Saturday only in the morning, between 8 and 11 a.m., and that stores are closed on Monday mornings and most other business are closed on Saturdays. Given these features of the data and the institutional context, below we describe the alternative hypotheses we test, and we detail the adopted identification strategies.

\footnotetext{
${ }^{17}$ Note that this standard approach does not exclude that individuals might derive intrinsic benefits from performing a costly effort. The original critiques by Solow (1971) and Arrow (1972) to Titmuss' (1971) conjectures about the negative impact of monetary incentives on blood donation, for example, were not excluding the presence of purely altruistic motives: They were questioning, instead, the presence of a conflict between different motives.
} 


\subsubsection{The choice of the donation day}

Consider, first, the reaction of existing donors to different extrinsic incentives. For donors who are employees, Law 584 essentially allows to choose from a menu of material incentives of various magnitude. Since donations can be made only in the morning and most donors-empoyees are free on Saturdays, donating on Fridays potentially leads to the highest material benefit (if leisure is taken as a good), since the donor-employee has, in fact, 2.5 consecutive days off available after the donation (excluding the morning of Friday). Donating on Mondays leads to having "only" two full consecutive days off; moreover, a Monday donation and consequent day off might be less rewarding since most stores are closed on Monday morning, therefore the paid time off has a smaller set of activities in which to be spent. Any other day of the week allows for only one, "isolated" day off, and finally, for those workers who have Saturday off by contract, a Saturday donation does not bring any material benefit. The highest explicit benefit, call it $y^{H}$, is received if the donor donates (i.e., $a=1$ ) on a Friday, according to our previous arguments. An intermediate benefit, $y^{M}$, is received from Monday to Thursday, and zero explicit benefit, $y^{L}=0$, from donating on a Saturday (for simplicity, we equate Mondays to any other weekday). The donor therefore compares these three utility levels:

$$
\begin{aligned}
U^{F} & =v_{a}+v_{y} y^{H}+m_{a} E\left(v_{a} \mid y^{H}\right)-m_{y} E\left(v_{y} \mid y^{H}\right)-c(1) ; \\
U^{W} & =v_{a}+v_{y} y^{M}+m_{a} E\left(v_{a} \mid y^{M}\right)-m_{y} E\left(v_{y} \mid y^{M}\right)-c(1) ; \\
U^{S} & =v_{a}+m_{a} E\left(v_{a} \mid y^{L}=0\right)-m_{y} E\left(v_{y} \mid y^{L}=0\right)-c(1) .
\end{aligned}
$$

Given her own type, the size of the explicit incentive, and the impact of her choice of the donation day on her social or self image, the donor will choose the donation day that maximizes her utility. If we observe employees clustering their donations on Fridays, for example, this would imply that $U^{F}>U^{W}$ and $U^{F}>U^{S}$, and therefore material incentives dominate over other drivers, consistent with standard economic intuition. If the bulk of donations are observed on Saturdays, instead, this would be evidence consistent with agents preferring not to receive any extrinsic benefits. A large share of donations on both Fridays and Saturdays might indicate that smaller rewards are even less appealing than no rewards, as the negative image consequences are greater than the direct gains. However, when explicit rewards are high enough, then donors respond positively to them. By contrast, a majority of donations in weekdays different from Friday would indicate that smaller rewards provide a better balance between the positive impact of direct material incentives and the negative impact on image from taking on those rewards. The longitudinal nature of our data also allows us to record the donation-day choice of each individual multiple times. We can therefore assess whether different habits by different donors emerge, thus hinting at some heterogeneity in the level of altruism, response to material incentives, and concerns for image being present in the population. 
The data also provides two different "control groups" against which to interpret the donation behavior of donors-employees. These groups are composed of employers and self-employed donors on the one hand, and donors who are out of the labor force on the other hand. Neither group of donors is affected by the paid-day-off provision. However, these two groups differ in terms of their potential incentives to donate throughout the week. A self-employed or business owner will be faced with a menu of two levels of economic incentives. If, for example, the business is closed on Saturday (or Monday, as in the case of stores), there is no direct economic loss from donating on Saturday (Monday). As for donors out of the labor force, intrinsic and extrinsic incentives, as defined here, should not change across different days of the week. If donors are attentive to economic incentives when making their donation decisions, then we would expect business owners to cluster their donations on the days when their businesses are closed in any case. We would also see the donation patterns of those out of the labor force to be distributed more evenly throughout the week than either employees or business owners.

\subsubsection{The choice of donation frequency}

In addition to studying the distribution of donations across the days of the week, and the presence of different "types" of donors in terms of their reaction to material incentives, we investigate whether the paid-day-off provision leads to an increase in the number of donations by donors affected by the policy. In terms of the theoretical framework outlined above, if the choice variable $a$ represents the number of donations, say, per year, then the analysis may be seen as one determining how different levels of the incentive $y$ affect the number of donations.

The fact that the day-off provision was in place throughout the entire period covered by our data presents some challenges to estimating its impact, in particular on the extensive margin, i.e., whether the provision attracted new donors. Aggregate time series on the number of AVIS members at the national level, however, do not show any decline in the number of blood donors following the introduction of the day-off privilege in 1967, and, if anything, the increase in donors immediately after 1967 was above the trend (see Figure 10). This evidence is consistent with the absence of any "crowding out" at the extensive margin. Moreover, the structure of our data, even if they start after the introduction of the day-off provision, allows us to obtain a reliable estimate of the effect of the policy on the intensive margin. In particular, we exploit the fact that a group of donors who are active in the 1985-89 period are still active donors in the 2002-06 period, and a subset of these donors changed labor market status in the second period relative to the first period. Our strategy will use donors who are active in both periods and have not changed labor market status as a control group, and will implement a difference-in-differences methodology where the two "treatment" groups are: (1) donors who were self-employed or out of the labor force in the first period and became employees in the second period, and (2) donors who were employees in the first period and became self-employed or left the labor force in the second period. If the day-off incentive does play a role in the donors' choice of the frequency of donation, we expect 
to observe an increase in the donation frequency of group (1) and a decrease in the frequency of group (2) relative to the group of donors who do not change labor market status. As with any difference-in-differences estimation, our identifying assumption is that, in the absence of the policy, the average outcomes for the "treated" (i.e., occupation switchers) and "control" (i.e., those who do not change occupation) groups would have followed parallel paths over time. In the analysis below we provide a discussion of whether this assumption is likely to be satisfied in our setting and perform a number of robustness checks.

\section{Empirical Results}

The competing predictions outlined above will be tested against our data on The Town's blood donors. First, we focus on whether the choice of donation days by donors is consistent with extrinsic incentives adding to altruistic motives, or whether donors give up additional material awards by choosing days with lower or no rewards. Second, we assess whether the provision of a day off increases the number of donations by donors affected by the policy.

\subsection{Economic considerations and the choice of donation days}

Figures 1 and 2 report the distribution of donations across the days of the week by donors' labor market status, pooling the data from the two periods. ${ }^{18}$ Overall, Saturday emerges as the day in which most donations occur - about four percentage points above a case of uniform distribution of donations across days (i.e., $100 \% / 6=16.7 \%$ ). When we disaggregate the distribution of donations by the job status of the donors, however, we uncover substantial differences. Focusing on employees only, Saturday remains the day with most donations, but a larger-than-average number of donations, around 20\%, occur on Fridays. This "Friday effect" is peculiar to employees. The "excess fraction" of Friday donations (fraction Friday minus 16.7\%) is equal to $+3.26 \%$ for employees, with a statistically significant $t$-ratio of 8.77 , against $-0.96 \%$ (not statistically different from zero) for the unemployed and donors out of the labor force, and a statistically significant $-4.9 \%$ for the selfemployed $(t$-ratio $=-6.29)$. Donations by the self-employed are strongly clustered on Mondays and Saturdays. In Figure 3, where we disaggregate the employers so as to isolate the store owners from the other entrepreneurs and self-employed, we notice that the store owners' donations are clustered on Mondays, when stores are closed, and the other employers' donations are concentrated on Saturdays, when the other businesses are closed. Finally, the donations by donors who are out of the labor force are virtually uniformly distributed across weekdays. ${ }^{19}$

\footnotetext{
${ }^{18}$ Note that the distribution of donations across weekdays for all donors is virtually identical to that for donors with non-missing labor market status. This indicates that the donors for whom the AVIS data contain labor market information are essentially a random sample of the population of donors. In the remainder of the paper, we will limit our attention to donors with non-missing labor market status information. Also, we replicated all of the analysis performed in this section separately by period (1984-1988 and 2002-2006), and the results were very similar.

${ }^{19}$ The findings are very similar when we treat the day right before a series of national holidays as a Friday, and the day after the holidays as a Monday. Holidays include January 1st, January 6th (the Epiphany), April 25th
} 
[Figures 1 and 2 about here]

[Figure 3 about here]

In sum, all categories of workers appear to choose their donation days in a way consistent with economic considerations entering with the standard sign into the utility function of donating blood: Employees tend to exploit the long-weekend opportunity; entrepreneurs, who cannot enjoy a fully paid day off, donate mostly on days when they would not have economic losses; and donors out of the labor force, who do not have any positive or negative economic return from any day they choose, display a uniform donation pattern throughout the week. For employees, in particular, economic considerations, therefore, seem to prevail over concerns for the social stigma from donating on a "mixed signal" day. At the same time, however, Saturday appears as the preferred day by a large set of the donor population, including employees. These seemingly contradictory findings are, in fact, consistent with the notion, postulated by the theory outlined in Section 3, that the overall population of donors is heterogeneous in terms of the importance attached to social considerations. It is also possible, however, that the sheer economic cost and benefits might differ for different donors, regardless of their altruistic attitudes and concerns about the social signal they send by donating in a given day. To further investigate the possibly different sources of the observed heterogeneity, we perform two exercises. In the first analysis, we ask whether donors show stable patterns of behavior so as to indicate the existence of "types." In the second, we divide the sample based on a priori differences in the economic advantage of donating in a given day and we explore whether we can detect different behaviors.

Thanks to the longitudinal nature of our data, we observe the same donor multiple times. Taking the donor as the unit of observation, we compute the modal donation weekday for each donor in each of the two periods. ${ }^{20}$ Figure 4 reports the distribution of the modal donation day by donors' labor market status. Since the patterns are fairly similar across periods, we focus on the most recent one because of the lager sample size. Figure 4 reveals that Saturday is the preferred donation day for 28 percent of the donors-employees, followed by Friday, which is preferred by 27 percent. The rest of the weekdays are preferred by 9 to 13 percent of donors-employees. As for the self-employed, they tend to prefer Mondays and Saturdays, consistent with the discussion above, while donors out of the labor force have more uniform preferences, with some overall preference, however, for Saturday.

[Figure 4 about here]

Further investigation confirms that these represent stable patterns of behavior. For example, about 70 percent of donors-employees whose modal donation day is Friday never donate on Sat-

(Liberation Day), May 1st (Labor Day), June 2nd (Republic Day), August 15th (Assumption Day), November 1st (All Saints Day), December 8th (Immaculate Conception Day) and December 25th (Christmas Day).

${ }^{20}$ To ensure that we compute meaningful modes, we restrict our attention to donors with at least 5 donations per period. We have repeated our exercises with more stringent criteria (e.g., donors with at least 10 donations per period) with virtually identical patterns. Our results, including those in the regressions presented below, are also robust with respect to different rules to break "ties" in the computation of modal donation days. 
urday, and about 50 percent of donors-employees whose modal day of donation is Saturday never donate on Friday or Monday. Moreover, donors whose modal donation day is Friday are not different from donors whose modal donation day is Saturday along a number of observable characteristics, including gender, age and occupation (see Table 4). These findings are consistent with presence of different "types" of contributors, as postulated in the framework of Benabou and Tirole (2006).

[Table 4 about here]

In order to further explore if the heterogeneity in donation day preference is attributable to different attitudes or just different economic cost-benefit considerations, we have broken down donor employees by the type of employer (we have this additional information only on a subset of employees and for the period 1985-89): small firms and large firms. We do not have direct information on such measures of size as number of employees or revenues. However, given the economic structure of The Town, the vast majority of private and local employers (i.e., those firms which are not part of a large, national company) can be reasonably classified as small. Large firms include banks, private or publicly owned companies offering public services such as utilities (electricity, telephone), and companies with a presence on a national level which also operate in The Town. Arguably, workers in small firms will be more constrained in their ability to take a day off. Anecdotal evidence indicates that this is indeed the case, as workers in small firms who take a day off are typically required to make up for the time lost by exerting extra effort upon their return. Workers in large firms might be less "indispensable," therefore bearing a lower cost from leaving work during a business day. Furthermore, although employers cannot prevent a worker from taking the day off for the purpose of donating blood, the fear of being fired might induce employees to limit their use of the incentive. This concern is likely to be higher in small firms, since the Italian law grants higher protection in case of an unfair layoff to workers in large firms than to those in smaller firms. (Garibaldi, Pacelli and Borgarello, 2004). ${ }^{21}$ Our conjecture is consistent with the findings reported in Figures 5 and 6, for Employees in small firms have the lowest preference for donating on Fridays or any other business days, while workers in large firms predominantly prefer to donate on Friday: About 50\% of employees in large firms have Friday as their modal donation day, followed by $20 \%$ whose modal day is Monday; fewer than 10 percent of employees in large firms choose Saturday as their preferred donation day. These findings, again, are consistent with donors responding positively to economic incentives. Still, heterogeneity remains among donors, even within a job category. In small firms, for example, $25 \%$ of employees have Friday as their modal donation day and $30 \%$ choose Saturday.

[Figures 5 and 6 about here]

The relations we found in the raw data are robust to controls in regression analyses. Table 2 presents a series of estimates of the effect of belonging to different labor market categories on

\footnotetext{
${ }^{21}$ Ichino and Riphahn (2005) show that the provision of employment protection does indeed cause greater absenteeism among Italian workers.
} 
(1) the conditional probability of donating on a Friday and (2) the conditional probability that a donor's preferred (modal) day of donation is a Friday. In the first set of regressions the unit of observation is given by the donation, while in the second set each observation is a donor-period pair. Controls include sex, age dummies, period effects (for 1985-89 and 2002-06), and year effects in all specifications, and the standard errors are adjusted for clustering on labor market status and period. Our main coefficient of interest is that on the indicator variable for the donor being an employee. This coefficient estimate is consistently positive and statistically significant, indicating that employees have a higher conditional probability to donate on Friday as well as a higher probability of choosing Friday as their preferred donation day compared to the baseline group of donors who are not employed, as well as compared to the self-employed. In Table 3 we report the coefficient estimates from running multinomial logit models with four possible outcomes. In the first set of regressions, the four outcomes are donating on (1) Monday, (2) Tuesday through Thursday, (3) Friday and (4) Saturday. In the second set of regressions, the four outcomes are given by the donors' modal donation days. The results from Panel A of Table 3 confirm that donors-employees are significantly more likely to donate on Friday than on any other day of the week (with the exception of Saturday) compared to donors who are out of the labor force as well as compared to the self-employed. The results from Panel B confirm that donors who are employees are more likely to choose Friday as their preferred donation day rather than any other day of the week, including Saturday. In particular, the odds of an employee donating on Friday rather than on Tuesday-Thursday are 1.46 times greater than for a donor who is non-employed and 2.56 times higher than for donors who are self-employed. Further, the odds of an employee choosing Friday rather than Tuesday-Thursday as his/her favorite donation day are 2 times higher than those of non-employed donors and 2.31 times higher than those of the self-employed.

[Table 2 about here]

[Table 3 about here]

\subsection{Does the day-off incentive lead to more donations?}

In the previous paragraphs we have established that a substantial fraction of donors who are employees appear to choose their preferred donation day in a way that allows them to maximize their extrinsic, economic benefit by extending their weekend. We have interpreted this finding as evidence that these donors do not seem to be concerned that donating on Friday might create ambiguity as to the true reason behind their altruistic actions. Our findings also suggest that the paid-day-off provision might induce donors-employees to donate more often than what they would do without the incentive. In the remainder of this section, we assess whether this is the case. As described in Section 3, we base our analysis on the set of donors who are present in both our sample periods (1985-89 and 2002-06) and, in particular, on the subset of these donors who have changed labor market status from one period to the next. We therefore exploit the within-donor shifts to 
determine whether changing labor market status is associated with different donation frequencies. The right-hand side of Table 1 describes the sample of donors who were active in both periods 1985-89 and 2002-06. This sample consists of 286 donors. Of the 153 donors for whom we have labor market status information in both periods, 97 maintain the same labor market status in 2002-06 as in 1985-89, while the remaining 56 changed status.

We begin by asking whether donors who are employees donate more or less frequently, in general, compared with other donors. Figure 8 shows the distribution of the number of donations per year by labor market status. The fraction of donors making just one donation a year is about 27 percent among employees, against 33 percent for the self-employed and 37 percent for the non-employed. Conversely, while 43 percent of employees make 3 or more donations a year, this fraction is just 36 percent among the self-employed and 31 percent for those out of the labor force. As can be seen in Figure 9, the same pattern is observed when we restrict the analysis to male donors only (a considerable fraction of donors out of the labor force are females, and women are limited by law in the number of donations they can make every year).

[Figures 8 and 9 about here]

The fact that donors-employees donate more frequently than both the self-employed and those out of the labor force is suggestive of an effect of the one-day paid leave of absence incentive. As a first step toward an evaluation of the causal nature of this finding, in columns (1) and (2) of Table 5 we report the results of individual fixed-effects regressions of the number of donations made by each donor each year on an employee indicator variable and a set of controls including age-group dummies, period effects (for 1985-89 and 2002-06), and year effects. The models we estimate are essentially difference-in differences models, where the control group consists of the donors who are never employees and hence never enjoy the day-off benefit. The coefficient on the employee indicator is the difference-in-differences estimator, identified, in our fixed-effects regressions, out of the donors who switch labor market status, transitioning in or out of the "employee" status. The inclusion of period effects and year effects ensures that the results are not driven by common trends, and the fixed-effects specification controls for unobservable, time-invariant donor-specific characteristics possibly correlated with the frequency of donation (including "intrinsic" altruism). In column (1), the sample consists of all donors observed in either 1985-89 or 2002-06 and with known labor market status, while in the remaining columns we restrict the sample to donors who are active in both periods. In columns (1) and (2), the coefficient estimate on the employee dummy is positive and strongly statistically significant. Its magnitude indicates that employees make, on average, about 0.65 more donations a year compared to non-employees.

[Table 5 about here]

Additional tests are performed to corroborate this finding. First, we recognize that if the incentive does affect the frequency of donations, it should do so in opposite ways for donors who 
were employees and became non-employees, and for donors who were non-employees and became employees, and we analyze in detail these two groups of donors. In columns (3) and (4) of Table 5 , we report results of fixed-effect regressions similar to those in columns (1) and (2), but we divide donors into four categories: a) donors who were employees in both 1985-89 and 2002-06, b) donors who were non-employees in both 1985-89 and 2002-06, c) donors who were non-employees in 1985-89 and became employees in 2002-06, and d) donors who were employees in 1985-89 and became non-employees in 2002-06. We define dummy variables for these groups and interact them with the dummy variable for period 2002-06. We perform the analysis on male and female donors together, as well as separately for males. ${ }^{22}$ Our difference-in-differences coefficients of interest are those on the interactions of the 2002-06 dummy and the labor market transitions indicators. The coefficient on the (2002-06) dummy is quite small and not statistically different from zero, which indicates that there was no significant change in the yearly frequency of donations for the baseline group (i.e., donors who were employees in both periods). The coefficient on the (2002-06)*(neveran-employee) interaction is also very small and not statistically different from zero. This indicates that donors who were not employees in both periods also did not experience a change in the number of yearly donations between the two periods. The coefficient on the $(2002-06) *($ other-to-employee) interaction, however, is positive and statistically significant, indicating that donors who became employees increased their donations compared to donors who did not change labor market status, net of year effects, period effects, and individual-specific fixed effects. In general (column 3) as well as in the case of males (column 4), the magnitude of the coefficient is substantial, since it suggests that donors who become employees, on average, increase their donations by about one donation per year. The coefficient on the $(2002-06) *($ employee-to-other) interaction, on the other hand, is negative and, in the case of males, statistically significant, which indicates that donors who ceased to be employees (and hence lose the incentive of the paid day off) reduced their donations by about 0.6 donations a year. We also report results from multinomial logit estimations of the differencein-differences models described above. Table 6 shows that there was, indeed, a switch from a low number of donations per year to a higher frequency for donors who became employees, and a switch away from high frequency to lower frequency for donors who were employees and entered another labor market status, thereby losing the day-off benefit.

The second set of robustness checks concerns the crucial identifying assumption that the average outcomes for the "treated" (i.e., occupation switchers) and "control" (i.e., those who do not change occupation) groups would have followed parallel paths over time in the absence of the policy. In other words, our interpretation of the effect of the day-off provision on the number of donations is valid provided that no other factor which is associated with changing occupation is systematically associated with donation frequency. The two main changes associated with changing labor market

\footnotetext{
${ }^{22}$ Because of the very small size of the female subsample (just 15 individuals), we are not able to obtain meaningful estimates for this group of donors.
} 
status and which could, in principle, also be associated with changes in donation behavior, are changes in family structure and changes in health. ${ }^{23}$ In an attempt to limit the potential bias (the sign of which is, moreover, unclear) coming from these forces, we exploit the fact that both these changes are strongly associated with aging. While all of the donors who are active in both 1985-89 and 2002-06 are aging at the same rate, not all donors started at the same point. In particular, those who were out of the labor force and then became employed were, in 1985-89, of relatively young age (29 years old on average). Conversely, those who were employees and then left the labor force were relatively older in the first period. Even though our difference-in-differences regressions did include age-group dummies, it is possible that the (2002-06)*(labor-market-transition) dummies might be capturing age effects, possibly associated with changes in health or family structure. To explore this possibility, we conduct a series of robustness checks. First, in columns (5) and (6) of Table 5, we restrict the sample to donors of ages 18-32 and 20-30, respectively, in 1985-89. Although the sample size is substantially reduced, this restriction ensures that donors in the "treatment" and "control" groups are of comparable ages. The results of column (5) and (6) confirm and strengthen the previous findings, as they indicate that becoming an employee and ceasing to be an employee are associated with 1.0-1.6 additional donations per year and 1.4-1.5 less donations per year, respectively. In Table 7 we explicitly investigate the relationship between aging and donation frequency. In columns (1) through (4), we use all donors and all 22 years (1985-2006) in our dataset. Column (1) reports results from an OLS regression of the number of donations per donor per year on a series of age, gender, and year dummies, as well as a year-of-first-donation dummies. The coefficients on the age dummies are positive and statistically significant, although their magnitude is quite small. Once individual fixed effects are included (columns 2 through 4), the age coefficients become even smaller in magnitude (especially in the case of males) and statistically indistinguishable from zero, for the whole sample (column 2) as well as for the male (column 3) and female donors (column 4) separately. These results indicate that once individual heterogeneity is taken into account, there is no systematic relationship between age and donation frequency. The results are confirmed once we restrict the sample to donors active in both 1985-89 and 2002-06 (columns 5 and 6) and we reproduce our difference-in-differences estimations including both timeage and time-employment transitions interactions. In fact, we observe that the age dummies are never statistically significant while the sign, size, and significance of the employment transitions interactions (difference-in-differences estimates) are essentially unchanged compared to our main specification of Table 5 .

[Table 7 about here]

\footnotetext{
${ }^{23}$ The AVIS data do contain some health indicators, in particular blood pressure, height, and weight, but only for the period 1985-89.
} 


\section{$5 \quad$ Discussion and Concluding Remarks}

The findings of this paper suggest that individuals are responsive to economic considerations in their blood donation decisions in a way that is largely consistent with standard economic intuition. In fact, we found that a substantial fraction of donors who are employees choose their preferred donation day in a way that allows them to maximize their extrinsic, economic benefit by extending their weekend. This indicates that "material" considerations dominate over the potentially negative self- and social-image effects of responding positively to economic incentives. At the same time, we also find evidence consistent with the notion, postulated by the theory of Benabou and Tirole (2006), that the overall population of donors is heterogeneous in terms of the degree of intrinsic altruism and the relative importance they attach to economic rewards and concerns about their social image.

Our paper contributes to the ongoing debate on whether explicit incentives should be used to stimulate pro-social behavior, including blood donation and organ donation for transplants. ${ }^{24}$ A large body of literature argues against the provision of such incentives, on the basis that they might crowd out intrinsic motivation thus leading to a net reduction of pro-social behavior. ${ }^{25}$ The evidence we presented in this paper suggests that those concerns are not always warranted. Further research is needed to establish whether other forms of material rewards, e.g., paying donors with cash, would obtain the same results, and how the size of the reward influences behavior. Evidence from donor surveys suggests that donors might respond more negatively to cash rewards than to in-kind rewards of the same nominal value (Lacetera and Macis, 2008b), while the experiments of Mellstrom and Johanneson (2008) indicate that male donors are not negatively affected by cash rewards. Gneezy and Rustichini (2000), moreover, find a non-linearity in the response of pro-social behavior to material rewards, with small prizes reducing the provision of the altruistic activity, and larger prizes enhancing it. The paid-leave incentive analyzed in this paper could be seen as a large incentive, thus our findings are in line with the experimental evidence of Gneezy and Rustichini (2000). Additional research is warranted also on the structure of material rewards. For example, as noted above, the specific incentive studied in this paper is designed so that donors can decide not to take advantage of it, and therefore allows for different tastes and attitudes by potentially different donors to be satisfied. Other incentive schemes do not always allow for this flexibility.

The incentive we have studied, and its behavioral effects, have social welfare consequences in that they impact the voluntary supply of blood, and might inform associations and policymakers on how to reduce frequent situations of supply shortages. We found that in addition to affecting the choice of when to donate, the right to a paid leave of absence for employees is associated with an increase in yearly donations by this category of donors. These results indicate that removing the policy would likely result in a reduced number of donations. Welfare comparisons, however,

\footnotetext{
${ }^{24}$ On organ donations, see Becker and Elias (2007).

${ }^{25}$ In the case of organ donation, "repugnance" is also seen as a barrier to the creation of an explicit market for organs (Roth 2007.)
} 
have to balance the gains from the policy with its costs to taxpayers. A conservative measure of the gains (i.e., abstracting from extensive margin effects) is that the policy leads donors-employees to make one extra donation per year. The government, however, must finance all donations made by donors-employees, i.e., about three donations per donor per year. The evaluation is complicated by the difficulty to estimate the value of an extra pint of blood, but this paper has provided one essential ingredient that was previously absent from the debate.

\section{References}

[1] Akerlof, G., and Kranton, R., 2000: "Economics and Identity," Quarterly Journal of Economics, 115, $3,715-753$.

[2] Ariely, D., Bracha, A. and Meier, S. (forthcoming), "Doing Good or Doing Well? Image Motivation and Monetary Incentives in Behaving Prosocially," American Economic Review.

[3] Arrow, K.J., 1972: "Gifts and Exchanges," Philosophy and Public Affairs, 1, 4, 343-362.

[4] Becker, G.S. and Elias, J.J., 2007: "Introducing Incentives in the Market for Live and Cadaveric Organ Donations," Journal of Economic Perspectives, 21, 3, 3-24.

[5] Bénabou, R. and Tirole, J., 2006: "Incentives and Prosocial Behavior," American Economic Review, $96,5,1652-1678$.

[6] Caligaris, A.O., 2007: "Relazione del Presidente," 46th National Annual Conference, FIDAS.

[7] Deci, E.L., 1975: Intrinsic Motivation, Plenum Press.

[8] Dionne, G. and Vanasse, C., 1997: "Une évaluation empirique de la nouvelle tarification au Québec," in C. Gouriéroux and C. Montmarquette (Eds.) Économétrie Appliquée, Economica, 47-80.

[9] Frey, B.S. and Oberholzer-Gee, F., 1997: "The Cost of Price Incentives: An Empirical Analysis of Motivation Crowding-Out," American Economic Review, 87, 4, 746-755.

[10] Garibaldi, P., Pacelli, L. and Borgarello, A. , 2004: "Employment Protection Legislation and the Size of Firms," Giornale degli economisti e annali di economia, 63, 33-68.

[11] Gneezy, U., and Rustichini,A., 2000: "Pay Enough or Don't Pay At All," Quarterly Journal of Economics, August, 791-810.

[12] Goette, L., and Stutzer, A., 2008: "Blood Donation and Incentives: Evidence from a Field Experiment," IZA Working Paper 3580.

[13] Guiso, L., Sapienza, P. and Zingales, L., 2006: "Does Culture Affect Economic Outcomes?," Journal of Economic Perspectives, 20, 2, 23-48. 
[14] Harbaugh, W.T., 1998a: "What do Donations Buy? A Model of Philanthropy Based on Prestige and Warm Glow," Journal of Public Economics, 67, 269-284.

[15] Harbaugh, W.T., 1998b: "The Prestige Motive for Charitable Transfers," American Economic Review, $88,2,277-282$.

[16] Harrison, G. W. and List, J.A., 2004: "Naturally Occurring Markets and Exogenous Laboratory Experiments: A Case Study of the Winner's Curse," Economic Journal, 118, pp. 822-843.

[17] Hemobiotech, 2008: http://www.hemobiotech.com, site last visited on October 7th 2008.

[18] Healy, K., 2006: Last Best Gifts. Altruism and the Market for Human Blood and Organs, University Of Chicago Press.

[19] Ichino, A. and Riphahn, R.T., 2005: "The Effect of Employment Protection on Worker Effort - A Comparison of Absenteeism During and After Probation," Journal of the European Economic Association, March, 3, 1, 120-143.

[20] Independent Sector, 2006: "Value of Volunteer Time," available at http://unitedwaypike.veneziale.net/Volunteers/is-dollar-value.pdf.

[21] ISTAT (Istituto Italiano di Statistica), 2005: Le organizzazioni di volontariato in Italia, 2003.

[22] Lacetera, N. and Macis, M., 2008a: "Social Prestige and Pro-Social Behavior: An Empirical Examination," working paper.

[23] Lacetera, N. and Macis, M., 2008b: "A Survey of Blood Donors Attitudes and Beliefs," working paper.

[24] Lach, S. and Schankerman, M., 2008: "Incentive and Invention in Universities," RAND Journal of Economics, 39, 2, 403-433.

[25] Lazear, E., 2000: "Performance Payand Productivity," American Economic Review, 90, 5, 1346-1361.

[26] Lazear, E., Malmendier, U. and Weber, R., 2006: "Sorting in Experiments with Application to Social Preferences," NBER Working Paper 12041.

[27] Levitt, S.D. and List, A., 2007: "What Do Laboratory Experiments Measuring Social Preferences Tell Us About the Real World," Journal of Economic Perspectives, 117, 522, 1051-1072.

[28] List, J. A., 2006: "The Behavioralist Meets the Market: Measuring Social Preferences and Reputation Effects in Actual Transactions," Journal of Political Economy, 114, 1, 1-37.

[29] McCleary, R.M., and Barro, R.J., 2006: "Religion and Economy," Journal of Economic Perspectives, $20,2,49-72$. 
[30] Mellstrom, C. and Johannesson, M., 2008: "Crowding Out in Blood Donation: Was Titmuss Right?," Journal of the European Economic Association, 6, 4, 845-63.

[31] Meier, S., 2006: "A Survey of Economic Theories and Field Evidence on Pro-Social Behavior," FedBoston working paper.

[32] Nagin, D., Rebitzer J., Taylor, L., and Sanders, S., 2002: "Monitoring, Motivation and Management: The Determinants of Opportunistic Behavior in a Field Experiment" American Economic Review, 92, 4, 850-873.

[33] Nowak, M.A. and Sigmund, K., 2000: "Shrewd Investments," Science, 288, 5467, 819-820

[34] Polborn, M., 2007: "Competing for Recognition through Public Good Provision," CESifo working paper.

[35] Price, M.K., 2003: "Pro-Community Altruism and Social Status in a Shuar Village," Human Nature, 14, 2, 191-195.

[36] Roth, A. E., 2007: "Repugnance As a Constraint On Markets," Journal of Economic Perspectives, 21, 3, 37-58.

[37] Shearmur, J., 2007: "The real Body, Part I: Blood and Corpses," Policy, 23, 4, 28-32.

[38] Solow, R.M., 1971: "Blood and Thunder," Yale Law Journal, 80, 8, 1696-1711.

[39] Squires, J.E., 2002: "Artificial blood," Science, 295, 5557, 1002-1005.

[40] Tabellini, G., 2008: " The Scope of Cooperation: Values and Incentives," Quarterly Journal of Economics, 123, 3, 905-950.

[41] Titmuss, R.M., 1971: The Gift Relationship, London: Allen and Unwin.

[42] Wedekind, K., 1998: "Give and Ye Shall Be Recognized," Science, 280, 5372, 2070-2071. 


\section{A Tables}

\begin{tabular}{|c|c|c|c|c|c|c|c|c|}
\hline & \multicolumn{4}{|c|}{ All donors } & \multicolumn{4}{|c|}{ Donors active in both periods } \\
\hline & \multicolumn{2}{|c|}{ 1985-89 } & \multicolumn{2}{|c|}{$2002-06$} & \multicolumn{2}{|c|}{ 1985-89 } & \multicolumn{2}{|c|}{$2002-06$} \\
\hline \multicolumn{9}{|l|}{ A. Basic Characteristics } \\
\hline $\mathrm{N}$ of donors & \multicolumn{2}{|c|}{826} & \multicolumn{2}{|c|}{2,074} & \multicolumn{2}{|c|}{286} & \multicolumn{2}{|c|}{286} \\
\hline Females \% & \multicolumn{2}{|c|}{24.5} & \multicolumn{2}{|c|}{28.8} & \multicolumn{2}{|c|}{0.15} & \multicolumn{2}{|c|}{0.15} \\
\hline Age & $\begin{array}{c}\text { Mean } \\
37.8\end{array}$ & $\begin{array}{l}\text { Std.Dev. } \\
10.7\end{array}$ & $\begin{array}{c}\text { Mean } \\
40.3\end{array}$ & $\begin{array}{l}\text { Std.Dev. } \\
10.6\end{array}$ & $\begin{array}{c}\text { Mean } \\
34.8\end{array}$ & $\begin{array}{l}\text { Std.Dev. } \\
8.2\end{array}$ & $\begin{array}{c}\text { Mean } \\
48.7\end{array}$ & $\begin{array}{c}\text { Std.Dev. } \\
8.3\end{array}$ \\
\hline Body Mass Index & 24.6 & 3.3 & & & 24.4 & 3.1 & & \\
\hline Blood Pressure & 127.4 & 9.6 & & & 126.6 & 7.7 & & \\
\hline Donations/year & 2.4 & 1.1 & 2.3 & 1.5 & 2.6 & 1.0 & 2.6 & 1.6 \\
\hline \multicolumn{9}{|l|}{ B. Employment Status } \\
\hline & Males & Females & Males & Females & Males & Females & Males & Females \\
\hline Employees & 0.71 & 0.41 & 0.67 & 0.48 & 0.70 & 0.43 & 0.69 & 0.53 \\
\hline Employed in small firms & 0.63 & 0.40 & - & - & 0.66 & 0.43 & - & - \\
\hline Employed in large firms & 0.08 & 0.01 & - & - & 0.04 & 0.00 & - & - \\
\hline Self-Employed & 0.10 & 0.05 & 0.13 & 0.09 & 0.11 & 0.04 & 0.12 & 0.13 \\
\hline Store owners & 0.03 & 0.05 & 0.06 & 0.06 & 0.03 & 0.04 & 0.05 & 0.10 \\
\hline Other & 0.07 & 0.00 & 0.08 & 0.03 & 0.08 & 0.00 & 0.07 & 0.03 \\
\hline Non-employed & 0.19 & 0.54 & 0.19 & 0.44 & 0.19 & 0.52 & 0.19 & 0.33 \\
\hline Students & 0.17 & 0.25 & 0.13 & 0.22 & 0.17 & 0.35 & 0.02 & 0.03 \\
\hline Housekeepers & 0.00 & 0.27 & 0.00 & 0.15 & 0.00 & 0.17 & 0.00 & 0.23 \\
\hline Retired & 0.01 & 0.00 & 0.04 & 0.02 & 0.00 & 0.00 & 0.15 & 0.03 \\
\hline Other & 0.01 & 0.01 & 0.01 & 0.06 & 0.02 & 0.00 & 0.02 & 0.03 \\
\hline $\begin{array}{l}\mathrm{N} \text { donors with valid labor } \\
\text { market status information }\end{array}$ & 354 & 91 & 1,098 & 487 & 178 & 23 & 175 & 30 \\
\hline
\end{tabular}

Table 1: Descriptive Statistics of blood donors in The Town. Notes: A. Physical characteristics (BMI and blood pressure) are available only for the period 1985-89. B. The category "SelfEmployed" also includes entrepreneurs who employ other workers. 


\begin{tabular}{|c|c|c|c|c|c|c|c|c|}
\hline & \multicolumn{4}{|c|}{ 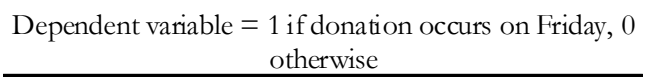 } & \multicolumn{4}{|c|}{$\begin{array}{c}\text { Dependent variable }=1 \text { if donor's modal donation day } \\
\text { is Friday, } 0 \text { otherwise }\end{array}$} \\
\hline & (1) & (2) & (3) & (4) & (5) & (6) & (7) & (8) \\
\hline & $\begin{array}{l}\text { Whole } \\
\text { Sample }\end{array}$ & $\begin{array}{l}\text { Whole } \\
\text { Sample }\end{array}$ & Males & Females & $\begin{array}{l}\text { Whole } \\
\text { Sample }\end{array}$ & $\begin{array}{l}\text { Whole } \\
\text { Sample }\end{array}$ & Males & Females \\
\hline Employee & $\begin{array}{l}0.0421^{\text {*k* }} \\
(0.007)\end{array}$ & $\begin{array}{l}0.0374^{* * * *} \\
(0.008)\end{array}$ & $\begin{array}{l}0.0359 * * * \\
(0.011)\end{array}$ & $\begin{array}{l}0.0410^{* * *} \\
(0.014)\end{array}$ & $\begin{array}{l}0.100^{* * *} \\
(0.027)\end{array}$ & $\begin{array}{l}0.104^{* * *} \\
(0.030)\end{array}$ & $\begin{array}{l}0.0990^{* *} \\
(0.039)\end{array}$ & $\begin{array}{l}0.0943^{* *} \\
(0.046)\end{array}$ \\
\hline Self-Employed & $\begin{array}{c}-0.0397 * * * \\
(0.010)\end{array}$ & $\begin{array}{c}-0.0445^{* * *} \\
(0.011)\end{array}$ & $\begin{array}{c}-0.0521 \text { *** } \\
(0.013)\end{array}$ & $\begin{array}{c}-0.00492 \\
(0.023)\end{array}$ & $\begin{array}{c}-0.0529 \\
(0.034)\end{array}$ & $\begin{array}{c}-0.0528 \\
(0.039)\end{array}$ & $\begin{array}{c}-0.0742^{*} \\
(0.044)\end{array}$ & $\begin{array}{c}0.0889 \\
(0.110)\end{array}$ \\
\hline Female & & $\begin{array}{c}-0.0256^{* * *} \\
(0.008)\end{array}$ & & & & $\begin{array}{c}-0.0585^{* *} \\
(0.028)\end{array}$ & & \\
\hline age $30-39$ & & $\begin{array}{c}0.00646 \\
(0.009)\end{array}$ & $\begin{array}{l}0.011 \\
(0.011)\end{array}$ & $\begin{array}{c}-0.0175 \\
(0.018)\end{array}$ & & $\begin{array}{c}-0.0282 \\
(0.036)\end{array}$ & $\begin{array}{c}-0.0506 \\
(0.044)\end{array}$ & $\begin{array}{c}0.0398 \\
(0.069)\end{array}$ \\
\hline age $40-49$ & & $\begin{array}{c}-0.013 \\
(0.009)\end{array}$ & $\begin{array}{c}-0.0133 \\
(0.011)\end{array}$ & $\begin{array}{c}-0.0118 \\
(0.017)\end{array}$ & & $\begin{array}{c}-0.0443 \\
(0.037)\end{array}$ & $\begin{array}{c}-0.0583 \\
(0.046)\end{array}$ & $\begin{array}{c}-0.00807 \\
(0.060)\end{array}$ \\
\hline age $50+$ & & $\begin{array}{c}-0.0276^{* k *} \\
(0.010)\end{array}$ & $\begin{array}{c}-0.0351 \text { *** } \\
(0.012)\end{array}$ & $\begin{array}{c}0.000453 \\
(0.018)\end{array}$ & & $\begin{array}{c}-0.0847 * * \\
(0.036)\end{array}$ & $\begin{array}{c}-0.114^{* *} \\
(0.045)\end{array}$ & $\begin{array}{c}0.00917 \\
(0.063)\end{array}$ \\
\hline 2002-2006 dummy & $\begin{array}{c}0.0122 \\
(0.016)\end{array}$ & $\begin{array}{c}0.0154 \\
(0.016)\end{array}$ & $\begin{array}{c}0.00777 \\
(0.018)\end{array}$ & $\begin{array}{l}0.018 \\
(0.034)\end{array}$ & $\begin{array}{c}-0.0205 \\
(0.063)\end{array}$ & $\begin{array}{c}0.0575 \\
(0.064)\end{array}$ & $\begin{array}{c}-0.0248 \\
(0.072)\end{array}$ & $\begin{array}{c}0.208^{* * *} * \\
(0.069)\end{array}$ \\
\hline Constant & $\begin{array}{c}0.147 * * * \\
(0.015)\end{array}$ & $\begin{array}{c}0.160^{* * * *} \\
(0.015)\end{array}$ & $\begin{array}{c}0.163^{* * *} * \\
(0.017)\end{array}$ & $\begin{array}{c}0.118^{* * * *} \\
(0.032)\end{array}$ & $\begin{array}{c}0.151^{* *} \\
(0.059)\end{array}$ & $\begin{array}{c}0.186^{* * * *} \\
(0.062)\end{array}$ & $\begin{array}{c}0.226^{* * *} \\
(0.072)\end{array}$ & $\begin{array}{c}-0.0595 \\
(0.046)\end{array}$ \\
\hline Observations & 16,618 & 16,578 & 13,139 & 3,439 & 1,308 & 1,304 & 1,020 & 284 \\
\hline R-squared & 0.01 & 0.01 & 0.01 & 0.01 & 0.03 & 0.04 & 0.04 & 0.04 \\
\hline
\end{tabular}

Table 2: Estimated effect of occupation on the conditional probability of donating on Friday and on Friday being the modal day of donation. Notes: Linear probability models on pooled 19851989 and 2002-2006 sample. The omitted category is non-employed males ages 18-29. Controls include period fixed effects and year fixed effects. Observations denote number of donations in (1) through (4) and number of donors in (5) through (8). In (5) through (8) only donors with at least 5 donations are included in the sample. Robust standard errors are reported in parentheses. *** $\mathrm{p}<0.01,{ }^{* *} \mathrm{p}<0.05, * \mathrm{p}<0.1$ 


\section{A. Dependent Variable: Day of Donation}

\begin{tabular}{|c|c|c|c|c|c|}
\hline & & \multicolumn{4}{|c|}{$\begin{array}{l}\text { Odds comparing alternative } \\
1 \text { to al ternative } 2\end{array}$} \\
\hline \multicolumn{2}{|c|}{ Employee vs Non-employed } & & & & \\
\hline Alternative 1 & Alternative 2 & Coefficient & $\mathrm{Z}$ & $\mathrm{P}>|\mathrm{z}|$ & $\mathrm{e}^{\wedge} \mathrm{b}$ \\
\hline Friday & Monday & 0.27 & 4.6 & 0.000 & 1.31 \\
\hline Friday & Tuesday-Thursday & 0.38 & 12.9 & 0.000 & 1.46 \\
\hline Friday & Saturday & -0.03 & -0.6 & 0.560 & 0.97 \\
\hline \multicolumn{6}{|c|}{ Employee vs self-Employed } \\
\hline Alternative 1 & Alternative 2 & Coefficient & $Z$ & $\mathrm{P}>|\mathrm{z}|$ & $\mathrm{e}^{\wedge} \mathrm{b}$ \\
\hline Friday & Monday & 0.94 & 8.4 & 0.000 & 2.56 \\
\hline Friday & Tuesday-Thursday & 0.38 & 13.3 & 0.000 & 1.47 \\
\hline Friday & Saturday & 0.82 & 6.1 & 0.000 & 2.26 \\
\hline Observations & \multicolumn{5}{|c|}{16,578} \\
\hline Wald Chi2 ( $\mathrm{p}>$ Chi2) & \multicolumn{5}{|c|}{$426.56(0.000)$} \\
\hline
\end{tabular}

B. Dependent variable: Donors' Modal Day of Donation

\begin{tabular}{|c|c|c|c|c|c|}
\hline & & \multicolumn{4}{|c|}{ Odds comparing alternative } \\
\hline \multicolumn{2}{|c|}{ Employee vs Non-employed } & & & & \\
\hline Alternative 1 & Alternative 2 & Coefficient & $\mathrm{Z}$ & $\mathrm{P}>|\mathrm{z}|$ & $\mathrm{e}^{\wedge} \mathrm{b}$ \\
\hline Friday & Monday & 1.02 & 3.6 & 0.000 & 2.78 \\
\hline Friday & Tuesday-Thursday & 0.77 & 3.5 & 0.000 & 2.16 \\
\hline Friday & Saturday & 0.32 & 1.4 & 0.170 & 1.37 \\
\hline \multicolumn{6}{|c|}{ Employee vs self-Employed } \\
\hline Alternative 1 & Alternative 2 & Coefficient & $\mathrm{Z}$ & $\mathrm{P}>|z|$ & $e^{\wedge} b$ \\
\hline Friday & Monday & 1.53 & 4.2 & 0.000 & 4.60 \\
\hline Friday & Tuesday-Thursday & 0.79 & 2.5 & 0.012 & 2.20 \\
\hline Friday & Saturday & 1.25 & 4.1 & 0.000 & 3.48 \\
\hline Observations & \multicolumn{5}{|c|}{1,304} \\
\hline Wald Chi2 ( $>>$ Chi2) & \multicolumn{5}{|c|}{$109.36(0.000)$} \\
\hline
\end{tabular}

Table 3: Friday Effect, multinomial logit analysis. In each panel, the first column reports the raw coefficients, the second the $\mathrm{z}$-score for test of coeff $=0$, the third the associated $\mathrm{p}$-value. The fourth column reports the factor change in odds of alternative 1 relative to alternative 2 for a unit increase in the independent variable. Controls include sex, age dummies, period fixed effects and year fixed effects. 


\begin{tabular}{|c|c|c|c|c|}
\hline & \multicolumn{2}{|c|}{$1985-1989$} & \multicolumn{2}{|c|}{$2002-2006$} \\
\hline & \multicolumn{2}{|c|}{ Modal donation day } & \multicolumn{2}{|c|}{ Modal donation day } \\
\hline & Friday & Saturday & Friday & Saturday \\
\hline Sex & 0.05 & 0.15 & 0.22 & 0.24 \\
\hline Age 18-29 & 0.25 & 0.21 & 0.14 & 0.13 \\
\hline Age 30-39 & 0.34 & 0.37 & 0.36 & 0.38 \\
\hline Age 40-49 & 0.33 & 0.32 & 0.35 & 0.33 \\
\hline Age $50+$ & 0.08 & 0.11 & 0.15 & 0.15 \\
\hline Blood type 0 & 0.59 & 0.57 & 0.50 & 0.51 \\
\hline Blood type A & 0.38 & 0.39 & 0.37 & 0.38 \\
\hline Blood type B & 0.00 & 0.05 & 0.09 & 0.08 \\
\hline Blood type $A B$ & 0.00 & 0.00 & 0.03 & 0.04 \\
\hline Years since joined AVIS & 7.07 & 6.16 & 7.23 & 6.71 \\
\hline $\mathrm{N}$ of donations per year & 2.43 & 2.47 & 2.53 & 2.30 \\
\hline White collar w orker & 44.29 & 35.37 & 50.41 & 46.24 \\
\hline Blue collar worker & 37.16 & 39.24 & 38.84 & 40.14 \\
\hline Teacher & 5.71 & 6.10 & 6.61 & 7.17 \\
\hline Driver (bus, taxi) & 2.86 & 9.76 & 0.41 & 1.08 \\
\hline Military, Police & 0.00 & 1.22 & 2.48 & 3.95 \\
\hline Store clerk & 2.86 & 1.22 & 0.41 & 0.36 \\
\hline Firefighter & 0.00 & 1.22 & 0.00 & 0.36 \\
\hline Other & 7.12 & 5.87 & 0.84 & 0.70 \\
\hline $\mathrm{N}$ of Donors & 70 & 82 & 242 & 279 \\
\hline
\end{tabular}

Table 4: Donors' observable characteristics by modal donation day (Friday or Saturday), and by period (1985-89, 2002-06). 


\begin{tabular}{|c|c|c|c|c|c|c|c|c|c|}
\hline & \multicolumn{9}{|c|}{ Dependent Variable: Number of donations per year } \\
\hline & \multirow[t]{3}{*}{ All donors } & \multicolumn{8}{|c|}{ Donors active in both $1985-1989$ and 2002-2006 } \\
\hline & & All donors & & & Donors with & known labo & market trans & tion & \\
\hline & & & All donors & Males & $\begin{array}{c}\text { Males ages } \\
18-32 \text { in } \\
1985-89\end{array}$ & $\begin{array}{c}\text { Males ages } \\
20-30 \text { in } \\
1985-89\end{array}$ & $\begin{array}{l}\text { All donors, } \\
1985 \text { and } \\
2002 \text { only }\end{array}$ & $\begin{array}{l}\text { Males, } \\
1985 \text { and } \\
2002 \text { only }\end{array}$ & $\begin{array}{c}\text { Males } 18-32 \text {, } \\
1985 \text { and } \\
2002 \text { only }\end{array}$ \\
\hline & $(1)$ & (2) & (3) & (4) & $(5)$ & $(6)$ & $(7)$ & $(8)$ & $(9)$ \\
\hline 2002-06 Dummy & $\begin{array}{l}-0.250 \\
(0.170)\end{array}$ & $\begin{array}{c}0.030 \\
(0.250)\end{array}$ & $\begin{array}{l}-0.285 \\
(0.320)\end{array}$ & $\begin{array}{l}-0.039 \\
(0.330)\end{array}$ & $\begin{array}{c}-0.122 \\
(0.760)\end{array}$ & $\begin{array}{c}-0.901 \text { *** } \\
(0.330)\end{array}$ & $\begin{array}{c}-0.682 \\
(1.030)\end{array}$ & $\begin{array}{c}-2.029 * \\
-1.200\end{array}$ & $\begin{array}{l}-1.161 \\
(1.670)\end{array}$ \\
\hline Employee Dummy & $\begin{array}{c}0.655^{* * *} \\
(0.210)\end{array}$ & $\begin{array}{c}0.656^{* * * *} \\
(0.210)\end{array}$ & & & & & & & \\
\hline$(2002-06) *($ Never an Employee) & & & $\begin{array}{c}0.040 \\
(0.300)\end{array}$ & $\begin{array}{c}0.059 \\
(0.330)\end{array}$ & $\begin{array}{c}0.434 \\
(0.510)\end{array}$ & $\begin{array}{c}0.221 \\
(0.740)\end{array}$ & $\begin{array}{c}0.145 \\
(0.440)\end{array}$ & $\begin{array}{c}0.082 \\
(0.490)\end{array}$ & $\begin{array}{c}0.503 \\
(1.070)\end{array}$ \\
\hline$(2002-06) *($ Employee-to-Other $)$ & & & $\begin{array}{l}-0.455 \\
(0.290)\end{array}$ & $\begin{array}{c}-0.586^{* *} \\
(0.280)\end{array}$ & $\begin{array}{c}-1.403^{* * *} \\
(0.350)\end{array}$ & $\begin{array}{c}-1.868^{* * *} \\
(0.290)\end{array}$ & $\begin{array}{l}-0.216 \\
(0.480)\end{array}$ & $\begin{array}{l}-0.362 \\
(0.490)\end{array}$ & $\begin{array}{c}-1.444^{*} \\
(0.840)\end{array}$ \\
\hline$(2002-06) *($ Other-to-Employee $)$ & & & $\begin{array}{c}0.840^{* *} \\
(0.380)\end{array}$ & $\begin{array}{c}0.921 * * \\
(0.430)\end{array}$ & $\begin{array}{c}1.390 * * \\
(0.640)\end{array}$ & $\begin{array}{l}1.489 \text { ** } \\
(0.730)\end{array}$ & $\begin{array}{c}1.309 * * \\
(0.540)\end{array}$ & $\begin{array}{c}1.422^{* *} \\
(0.580)\end{array}$ & $\begin{array}{c}2.340^{* *} \\
(1.060)\end{array}$ \\
\hline age $30-39$ & $\begin{array}{c}0.035 \\
(0.083)\end{array}$ & $\begin{array}{l}-0.052 \\
(0.220)\end{array}$ & $\begin{array}{l}-0.117 \\
(0.230)\end{array}$ & $\begin{array}{l}-0.176 \\
(0.250)\end{array}$ & $\begin{array}{l}-0.274 \\
(0.410)\end{array}$ & $\begin{array}{c}0.147 \\
(0.580)\end{array}$ & $\begin{array}{c}-1.270^{* * *} \\
(0.430)\end{array}$ & $\begin{array}{c}-1.223^{* * *} \\
(0.430)\end{array}$ & $\begin{array}{l}-1.453 \\
(0.880)\end{array}$ \\
\hline age $40-49$ & $\begin{array}{l}0.219 * \\
(0.130)\end{array}$ & $\begin{array}{c}0.175 \\
(0.290)\end{array}$ & $\begin{array}{c}0.161 \\
(0.330)\end{array}$ & $\begin{array}{l}-0.058 \\
(0.350)\end{array}$ & $\begin{array}{c}0.056 \\
(0.640)\end{array}$ & $\begin{array}{c}0.644^{* * *} * \\
(0.140)\end{array}$ & $\begin{array}{l}-0.816 \\
(0.630)\end{array}$ & $\begin{array}{l}-0.927 \\
(0.680)\end{array}$ & $\begin{array}{l}-1.281 \\
(1.260)\end{array}$ \\
\hline age $50+$ & $\begin{array}{c}0.119 \\
(0.170)\end{array}$ & $\begin{array}{c}0.056 \\
(0.430)\end{array}$ & $\begin{array}{c}0.019 \\
(0.480)\end{array}$ & $\begin{array}{l}-0.255 \\
(0.520)\end{array}$ & $\begin{array}{c}0.611 \\
(0.850)\end{array}$ & & $\begin{array}{c}-1.813^{* *} \\
(0.910)\end{array}$ & $\begin{array}{c}-1.749 * \\
(0.960)\end{array}$ & $\begin{array}{l}0.000 \\
0.000\end{array}$ \\
\hline Constant & $\begin{array}{c}2.046^{* * *} \\
(0.200)\end{array}$ & $\begin{array}{c}2.266^{* * *} * \\
(0.250)\end{array}$ & $\begin{array}{c}2.821^{* * *} \\
(0.200)\end{array}$ & $\begin{array}{c}2.886^{* * *} \\
(0.220)\end{array}$ & $\begin{array}{c}2.614 * * * \\
(0.210)\end{array}$ & $\begin{array}{c}2.678^{* * *} \\
(0.270)\end{array}$ & $\begin{array}{c}3.651^{* * *} \\
(0.340)\end{array}$ & $\begin{array}{c}3.699 * * * \\
(0.360)\end{array}$ & $\begin{array}{c}2.848^{* * *} \\
(0.350)\end{array}$ \\
\hline Donor-Year Observations & 6,916 & 1,593 & 1,221 & 1,111 & 408 & 288 & 306 & 276 & 86 \\
\hline $\mathrm{N}$ of donors $(\mathrm{FE})$ & 1,870 & 253 & 153 & 138 & 57 & 42 & 153 & 138 & 43 \\
\hline R-squared & 0.02 & 0.04 & 0.05 & 0.05 & 0.17 & 0.22 & 0.29 & 0.30 & 0.45 \\
\hline
\end{tabular}

Table 5: Number of donations per year: fixed effects regressions results. In (1) the sample includes all donors with valid labor market information. In (2) the sample includes donors who were active in both 1985-89 and 2002-06 and with valid labor market information. In (3) through (9), the sample includes only donors who are active in both periods, and with valid labor market status information for both periods. The omitted "job transition" category consists of donors who were employees in both 1985-89 and 2002-06. Controls include year fixed effects. Robust standard errors are reported in parentheses. Observations are donors-year. ${ }^{* * *} \mathrm{p}<0.01,{ }^{* *} \mathrm{p}<0.05,{ }^{*} \mathrm{p}<0.1$ 


\begin{tabular}{|c|c|c|c|c|c|c|c|c|c|}
\hline \multirow{3}{*}{\multicolumn{2}{|c|}{$\begin{array}{l}\text { \# donations } \\
\text { per year }\end{array}$}} & \multicolumn{8}{|c|}{ Employee to Other } \\
\hline & & \multirow{2}{*}{\multicolumn{4}{|c|}{$\begin{array}{c}\text { Odds comparing alternative } \\
1 \text { to alternative } 2 \\
\text { Males and Females }\end{array}$}} & \multicolumn{4}{|c|}{$\begin{array}{c}\text { Odds comparing alternative } \\
1 \text { to alternative } 2 \\
\end{array}$} \\
\hline & & & & & & & & & \\
\hline Alt. 1 & Alt. 2 & Coeff. & Z & $\mathrm{P}>|\mathrm{z}|$ & $\mathrm{e}^{\wedge} \mathrm{b}$ & Coeff. & Z & $\mathrm{P}>|\mathrm{z}|$ & $\mathrm{e}^{\wedge} \mathrm{b}$ \\
\hline 1 & 2 & -0.06 & -0.12 & 0.905 & 0.94 & -0.25 & -0.49 & 0.622 & 0.78 \\
\hline 1 & 3 & -0.16 & -0.32 & 0.747 & 0.85 & -0.22 & -0.42 & 0.676 & 0.80 \\
\hline 2 & 3 & -0.10 & -0.23 & 0.820 & 0.90 & 0.03 & 0.06 & 0.950 & 1.03 \\
\hline $4+$ & 1 & 1.08 & 2.21 & 0.027 & 2.93 & 1.27 & 2.43 & 0.015 & 3.57 \\
\hline $4+$ & 2 & 1.02 & 2.29 & 0.022 & 2.77 & 1.02 & 2.16 & 0.031 & 2.77 \\
\hline $4+$ & 3 & 0.91 & 1.97 & 0.049 & 2.50 & 1.05 & 2.14 & 0.032 & 2.85 \\
\hline \multirow{2}{*}{\multicolumn{2}{|c|}{$\begin{array}{l}\text { Observations } \\
\text { Wald Chi } 2 \text { ( } \mathrm{p}>\text { Chi } 2)\end{array}$}} & \multicolumn{4}{|c|}{1,221} & \multicolumn{4}{|c|}{1,111} \\
\hline & & \multicolumn{4}{|c|}{$89.64(0.0003)$} & \multicolumn{4}{|c|}{$78.77(0.003)$} \\
\hline \multirow{3}{*}{\multicolumn{2}{|c|}{$\begin{array}{c}\text { \# donations } \\
\text { per year }\end{array}$}} & \multicolumn{8}{|c|}{ Other to Employee } \\
\hline & & \multicolumn{4}{|c|}{$\begin{array}{c}\text { Odds comparing alternative } \\
1 \text { to alternative } 2\end{array}$} & \multicolumn{4}{|c|}{$\begin{array}{c}\text { Odds comparing alternative } \\
1 \text { to alternative } 2\end{array}$} \\
\hline & & \multicolumn{4}{|c|}{ Males and Females } & \multicolumn{4}{|c|}{ Males } \\
\hline Alt. 1 & Alt. 2 & Coeff. & Z & $\mathrm{P}>|\mathrm{z}|$ & $\mathrm{e}^{\wedge} \mathrm{b}$ & Coeff. & $\mathrm{Z}$ & $\mathrm{P}>|\mathrm{z}|$ & $\mathrm{e}^{\wedge} \mathrm{b}$ \\
\hline 1 & 2 & 0.37 & 0.74 & 0.461 & 1.45 & 0.33 & 0.63 & 0.530 & 1.39 \\
\hline 1 & 3 & 0.36 & 0.72 & 0.472 & 1.43 & 0.34 & 0.66 & 0.509 & 1.41 \\
\hline 2 & 3 & -0.01 & -0.03 & 0.979 & 0.99 & 0.01 & 0.03 & 0.977 & 1.01 \\
\hline $4+$ & 1 & -1.16 & -1.98 & 0.048 & 0.31 & -1.26 & -2.13 & 0.034 & 0.28 \\
\hline $4+$ & 2 & -0.78 & -1.47 & 0.141 & 0.46 & -0.93 & -1.74 & 0.083 & 0.39 \\
\hline $4+$ & 3 & -0.80 & -1.52 & 0.128 & 0.45 & -0.92 & -1.74 & 0.082 & 0.40 \\
\hline \multicolumn{2}{|c|}{ Observations } & \multicolumn{4}{|c|}{1,221} & \multicolumn{4}{|c|}{1,111} \\
\hline \multicolumn{2}{|c|}{ Wald Chi2 (p>Chi2) } & \multicolumn{4}{|c|}{$89.64(0.0003)$} & \multicolumn{4}{|c|}{$78.77(0.003)$} \\
\hline
\end{tabular}

Table 6: Effect of switching occupation on the number of donations per year. Notes: The Table reports results from estimating multinomial logit models. Each observation is a donor-year pair. The dependent variable can take four values: 1 donation per year, 2 donations, 3 donations and 4 or more donations per year. The independent variable of interest is a dummy variable indicating the labor market transition of an individual between the periods 1985-89 and 2002-06 interacted with a 2002-06 indicator variable. Controls include sex, age dummies and year fixed effects. In each panel, the first column reports the raw coefficients, the second the z-score for test of coeff=0, the third the associated p-value. The fourth column reports the factor change in odds of Alternative 1 relative to Alternative 2 for a unit increase in the independent variable. 


\begin{tabular}{|c|c|c|c|c|c|c|}
\hline & \multicolumn{6}{|c|}{ Dependent Variable: Number of donations per year } \\
\hline & \multicolumn{4}{|c|}{ All years $(1985-2006)$} & \multicolumn{2}{|c|}{$\begin{array}{c}\text { Donors active in both } 1985-1989 \\
\text { and 2002-2006 and with known } \\
\text { labor market transition (years } \\
1985-89 \text { and 2002-06) }\end{array}$} \\
\hline & $\begin{array}{c}\text { Males and } \\
\text { Females }\end{array}$ & $\begin{array}{c}\text { Males and } \\
\text { Females }\end{array}$ & Males & Females & $\begin{array}{c}\text { Males and } \\
\text { Females }\end{array}$ & Males \\
\hline & $(1)$ & $(2)$ & (3) & (4) & $(5)$ & $(6)$ \\
\hline Female & $\begin{array}{c}-0.494^{* * *} \\
(0.023)\end{array}$ & & & & & \\
\hline age $30-39$ & $\begin{array}{c}0.100 * * * \\
(0.025)\end{array}$ & $\begin{array}{c}-0.00588 \\
(0.044)\end{array}$ & $\begin{array}{c}-0.0462 \\
(0.047)\end{array}$ & $\begin{array}{l}0.0904 \\
(0.100)\end{array}$ & $\begin{array}{l}-0.165 \\
(0.260)\end{array}$ & $\begin{array}{l}-0.218 \\
(0.290)\end{array}$ \\
\hline age $40-49$ & $\begin{array}{c}0.240^{* * *} \\
(0.029)\end{array}$ & $\begin{array}{l}0.0753 \\
(0.072)\end{array}$ & $\begin{array}{l}0.0133 \\
(0.079)\end{array}$ & $\begin{array}{c}0.225 \\
(0.160)\end{array}$ & $\begin{array}{c}0.162 \\
(0.350)\end{array}$ & $\begin{array}{c}-0.0293 \\
(0.380)\end{array}$ \\
\hline age $50+$ & $\begin{array}{c}0.249 * * * \\
(0.038)\end{array}$ & $\begin{array}{l}0.0811 \\
(0.100)\end{array}$ & $\begin{array}{l}0.0053 \\
(0.110)\end{array}$ & $\begin{array}{c}0.268 \\
(0.210)\end{array}$ & $\begin{array}{c}0.111 \\
(0.450)\end{array}$ & $\begin{array}{l}-0.195 \\
(0.480)\end{array}$ \\
\hline 2002-06 Dummy & & & & & $\begin{array}{l}-0.141 \\
(0.450)\end{array}$ & $\begin{array}{c}0.129 \\
(0.450)\end{array}$ \\
\hline$(2002-2006) *($ age $30-39)$ & & & & & & \\
\hline$(2002-2006) *($ age $40-49)$ & & & & & $\begin{array}{l}-0.169 \\
(0.400)\end{array}$ & $\begin{array}{l}-0.231 \\
(0.410)\end{array}$ \\
\hline$(2002-2006) *($ age $50+)$ & & & & & $\begin{array}{l}-0.274 \\
(0.470)\end{array}$ & $\begin{array}{l}-0.248 \\
(0.480)\end{array}$ \\
\hline$(2002-06) *($ Never an Employee) & & & & & $\begin{array}{c}0.041 \\
(0.300)\end{array}$ & $\begin{array}{l}0.0456 \\
(0.330)\end{array}$ \\
\hline$(2002-06) *($ Employee-to-Other $)$ & & & & & $\begin{array}{l}-0.423 \\
(0.290)\end{array}$ & $\begin{array}{c}-0.551 * \\
(0.290)\end{array}$ \\
\hline$(2002-06) *($ Other-to-Employee) & & & & & $\begin{array}{c}0.826 * * \\
(0.400)\end{array}$ & $\begin{array}{c}0.906^{* *} \\
(0.440)\end{array}$ \\
\hline Constant & $\begin{array}{c}3.116^{* * *} \\
(0.240)\end{array}$ & $\begin{array}{c}2.516^{* * *} \\
(0.058)\end{array}$ & $\begin{array}{c}2.604 * * * \\
(0.066)\end{array}$ & $\begin{array}{c}2.294 * * * \\
(0.110)\end{array}$ & $\begin{array}{c}2.839 * * * \\
(0.210)\end{array}$ & $\begin{array}{c}2.895^{* * *} \\
(0.230)\end{array}$ \\
\hline Donor-Year Observations & 14,994 & 16,868 & 13,167 & 3,701 & 1,221 & 1,111 \\
\hline R-squared & 0.08 & 0.02 & 0.02 & 0.10 & 0.05 & 0.05 \\
\hline $\mathrm{N}$ of donors (FE) & & 2303 & 1618 & 685 & 153 & 138 \\
\hline
\end{tabular}

Table 7: Relationship between age and the number of donations per year. (1) reports results from an OLS regression using the entire sample of donors observed over years 1985-2006. Columns (2) through (6) report results from fixed effects regressions on various sub-samples. In columns (5) through (6), the omitted "job transition" category consists of donors who wee employees in both 1985-89 and 2002-06. Controls include year fixed effects and, in (1), year-of-first-donation fixed effects. Robust standard errors are reported in parentheses. Observations are donors-year. *** $\mathrm{p}<0.01,{ }^{* *} \mathrm{p}<0.05, * \mathrm{p}<0.1$ 


\section{B Figures}

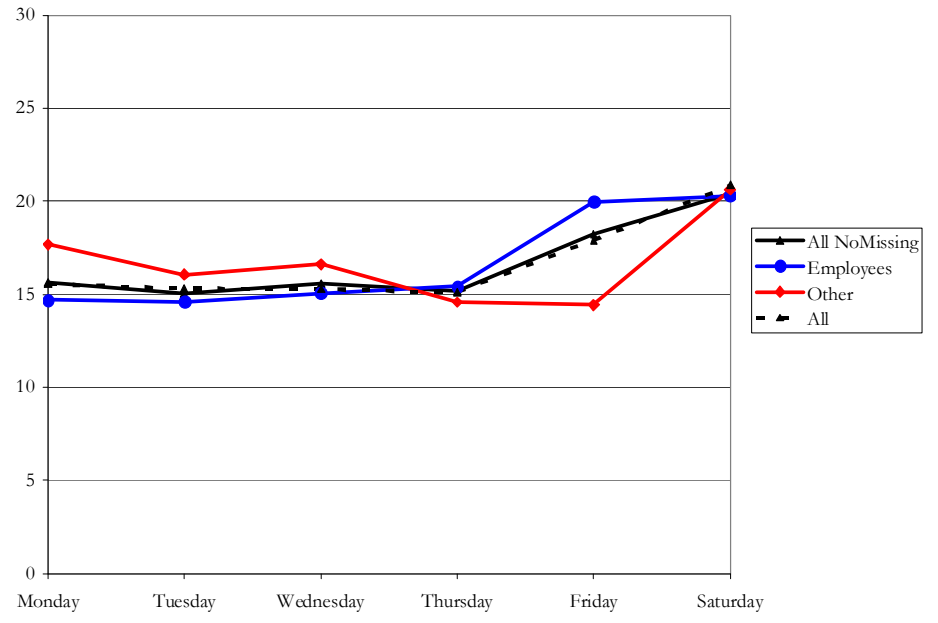

Figure 1: Distribution of donations by day of the week and labor market status, in \% terms. Pooled 1985-89 and 2002-06 data.

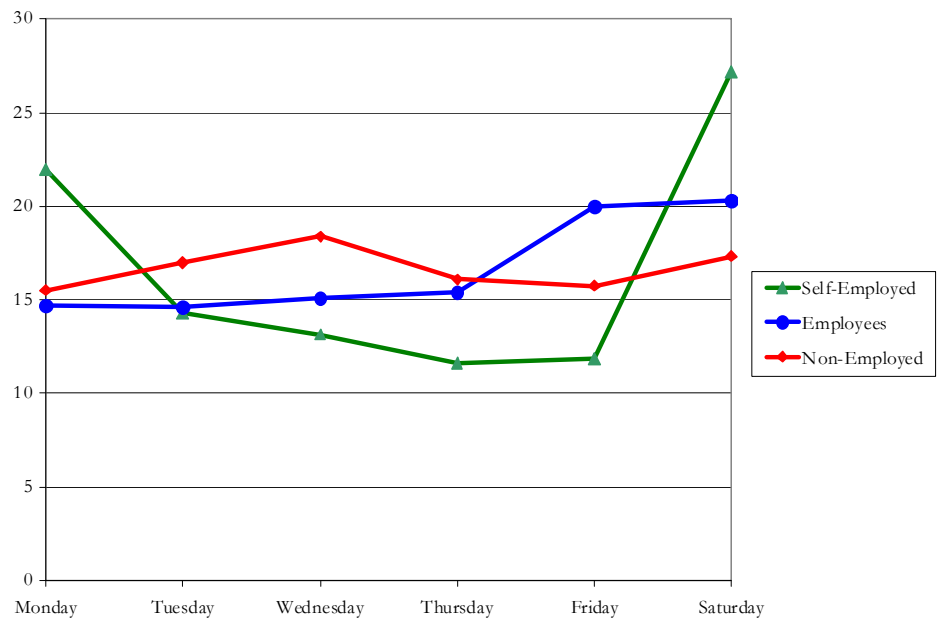

Figure 2: Distribution of donations by day of the week and labor market status, in $\%$ terms. Pooled 1985-89 and 2002-06 data. 


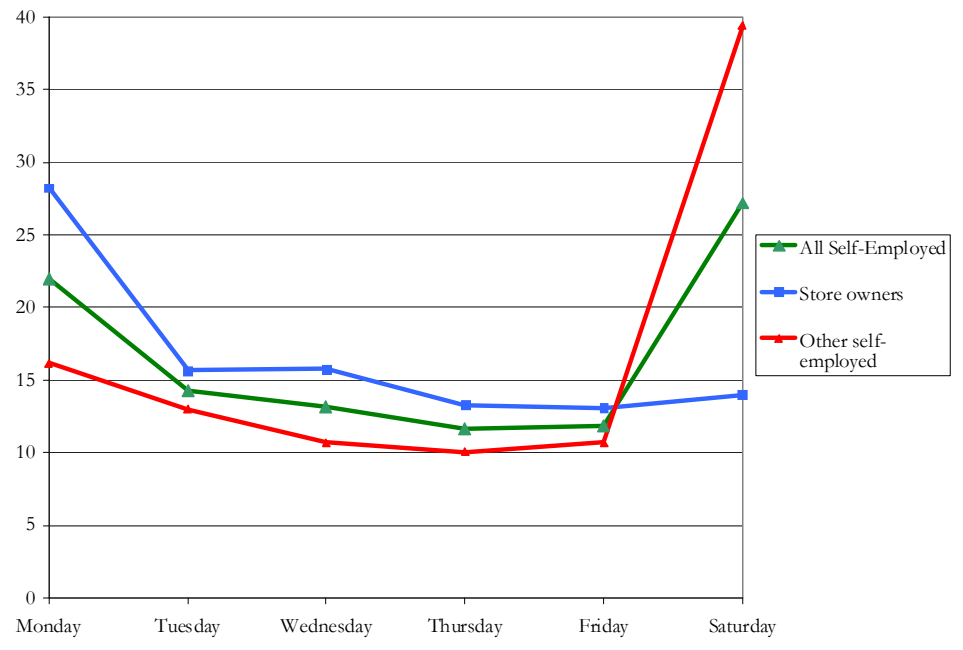

Figure 3: Distribution of donations by day of the week, in $\%$ terms, for entrepreneurs and selfemployed. Pooled 1985-89 and 2002-06 data.

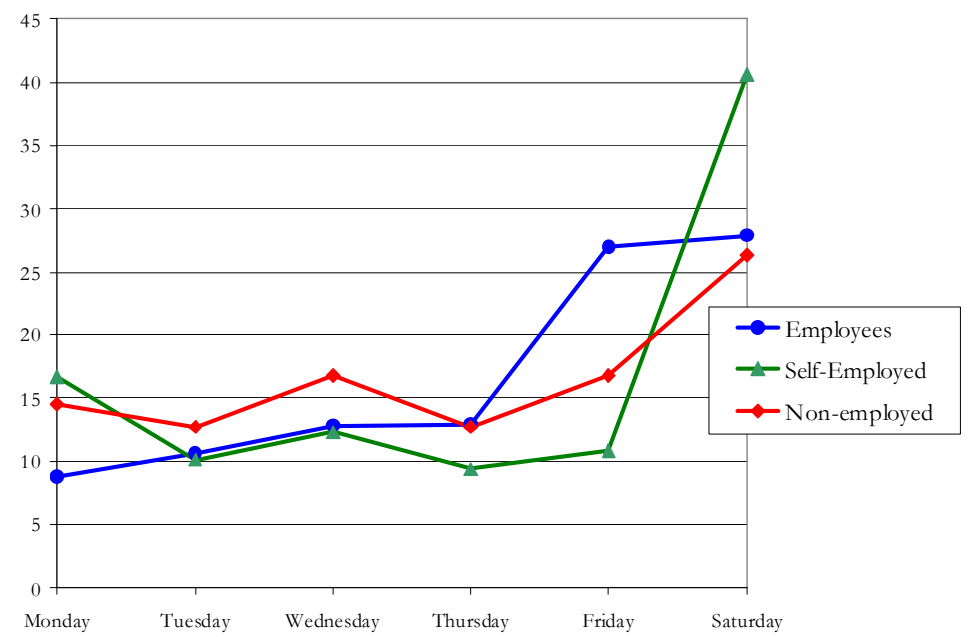

Figure 4: Distribution of the modal donation day by donors' labor market status. Pooled 1985-89 and 2002-2006 observations, limited to donors with at least 5 donations in at least one period. 


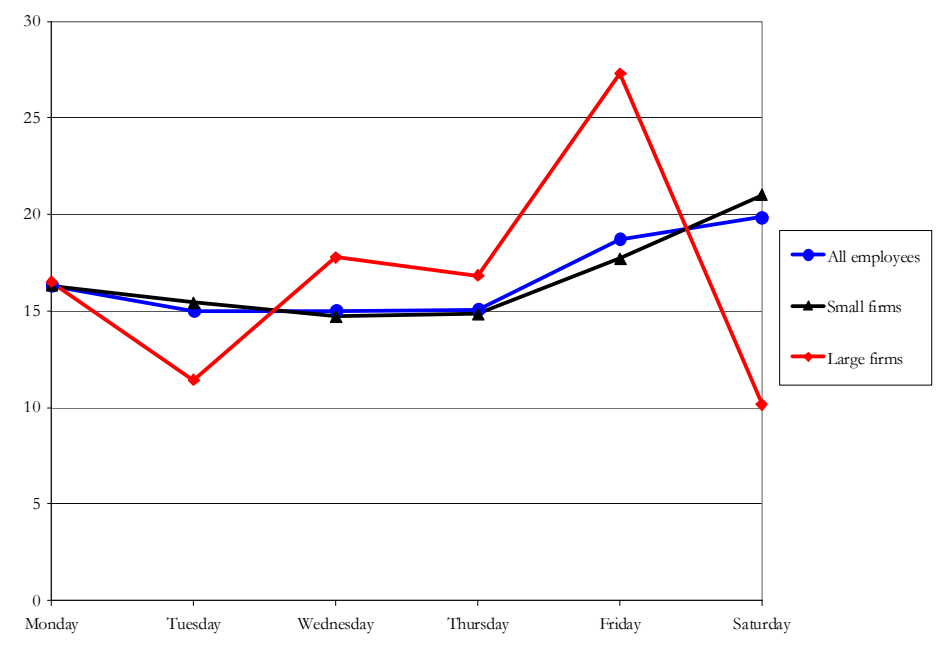

Figure 5: Distribution of donations by day of the week, in $\%$ terms, for employees, divided by those working in small and large firms. Information is available only for the 1985-89 data.

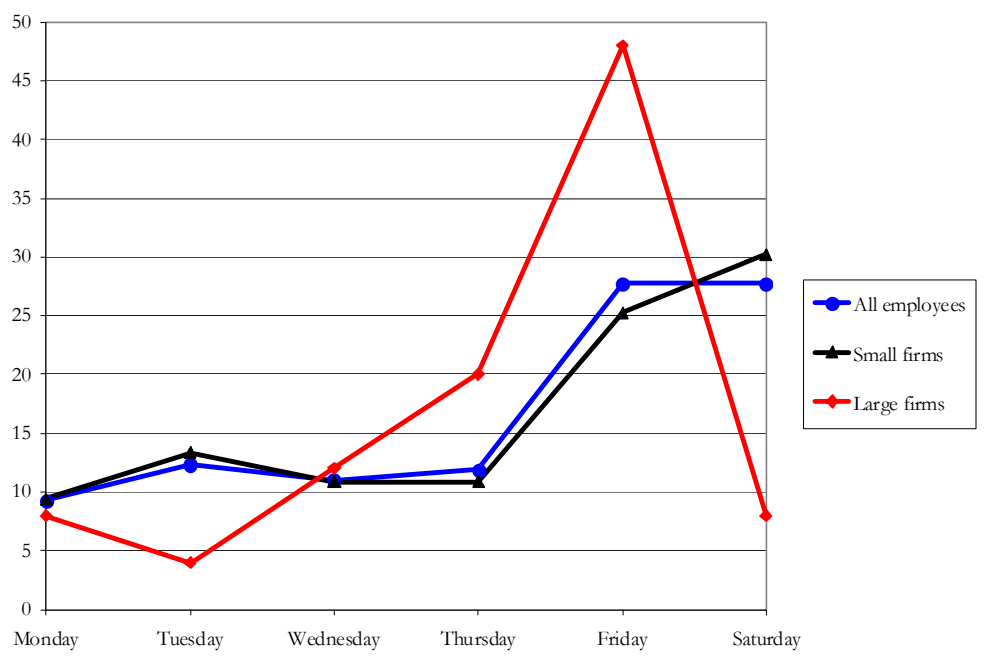

Figure 6: Distribution of the modal donation day, in \% terms, for employees, divided by those working in small and large firms. Information is available only for the 1985-89 data. 


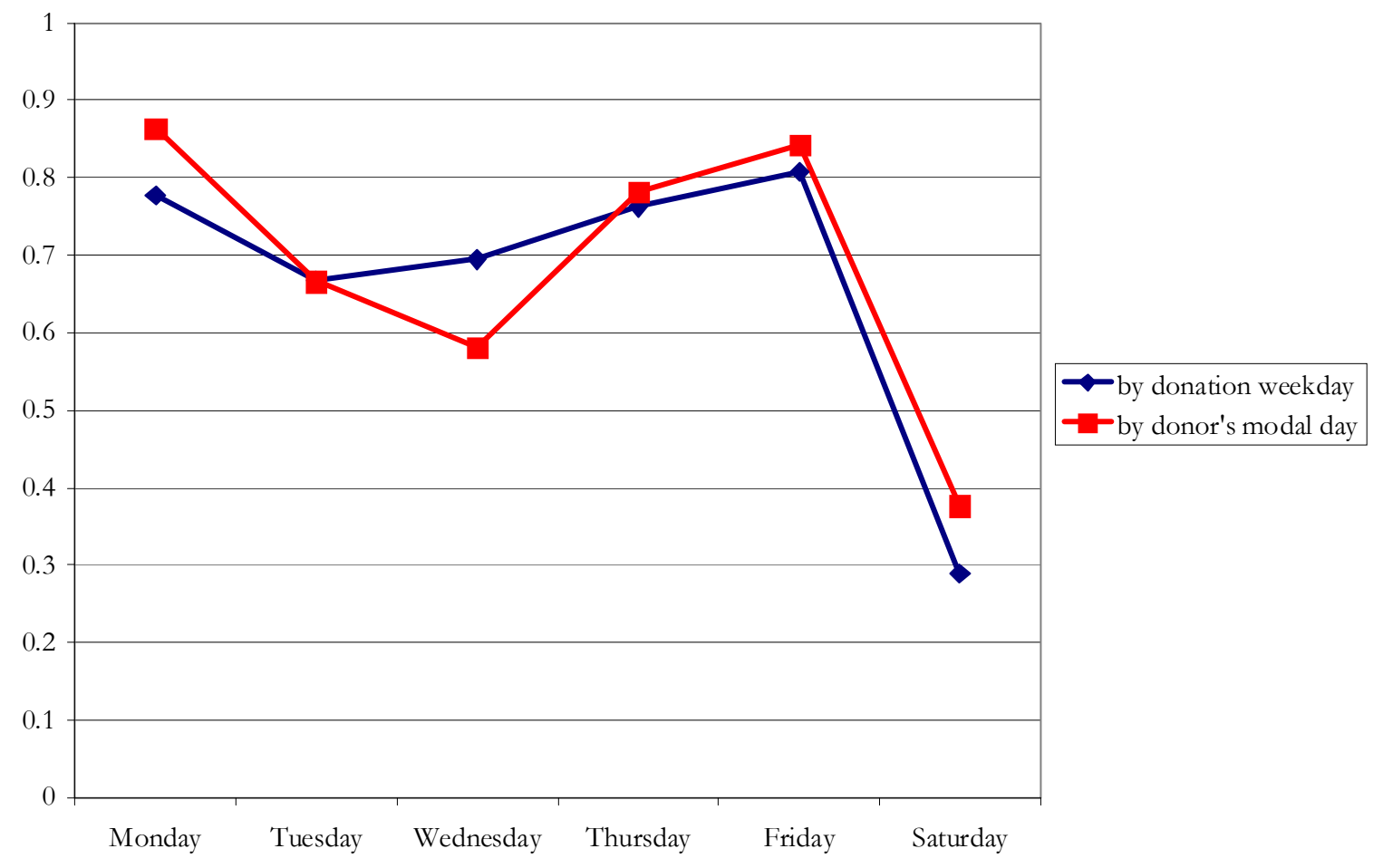

Figure 7: Paid leave of absence: take-up rates by donation weekday and by donors' modal donaiton day. Data are for 305 donations and 239 donors in year 2006. 


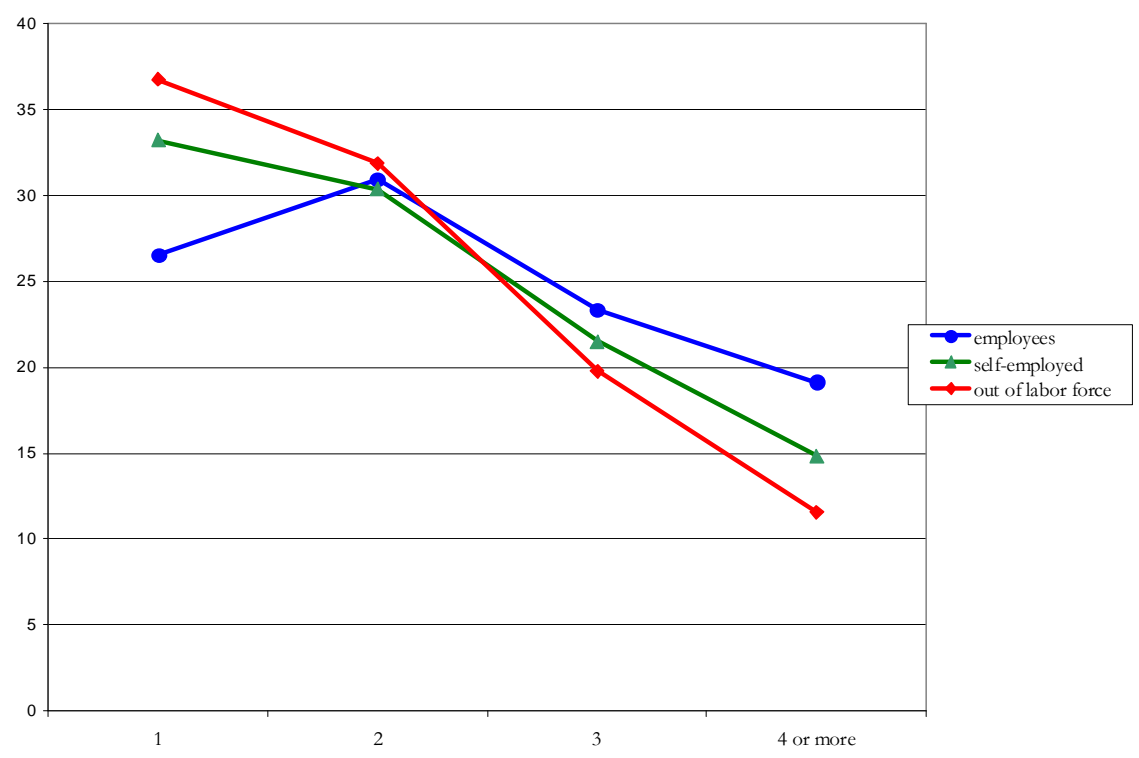

Figure 8: Distribution of Number of Donations per Year, by labor market status. Pooled 1985-89 and 2002-06 periods. Males and females.

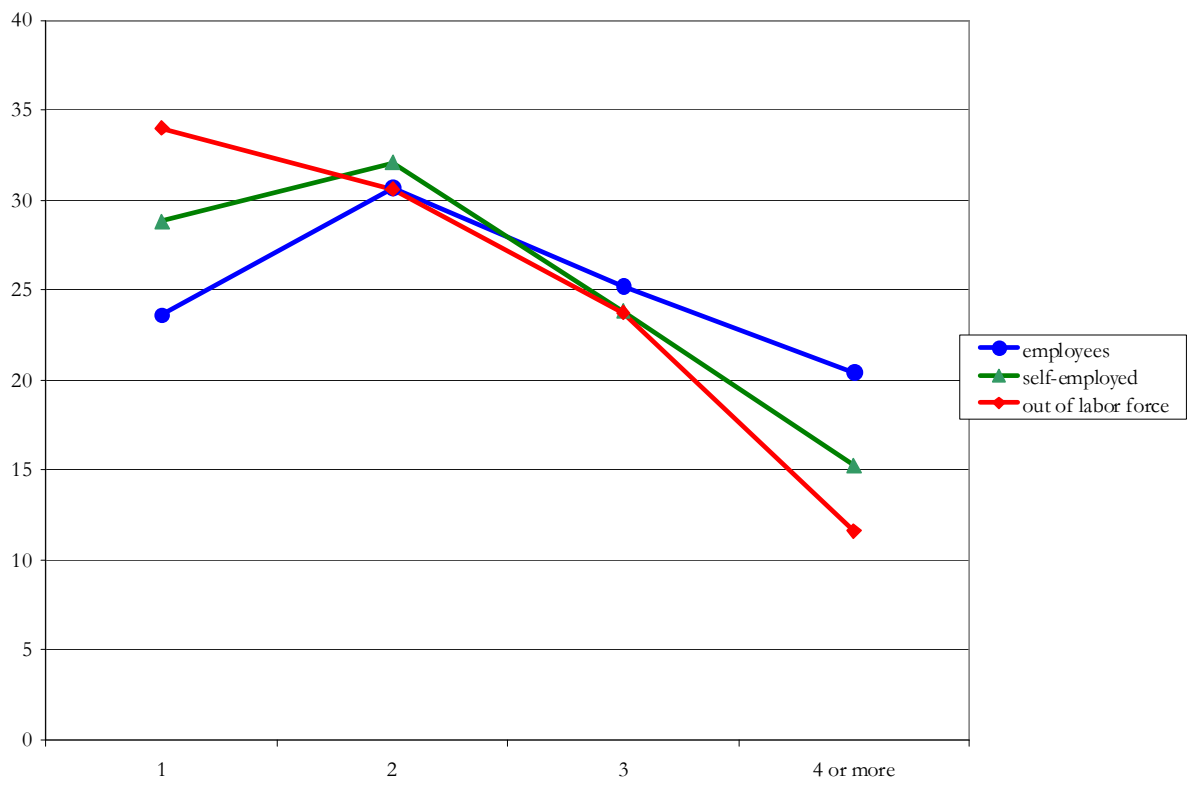

Figure 9: Distribution of Number of Donations per Year, by labor market status. Pooled 1985-89 and 2002-06 periods. Males. 


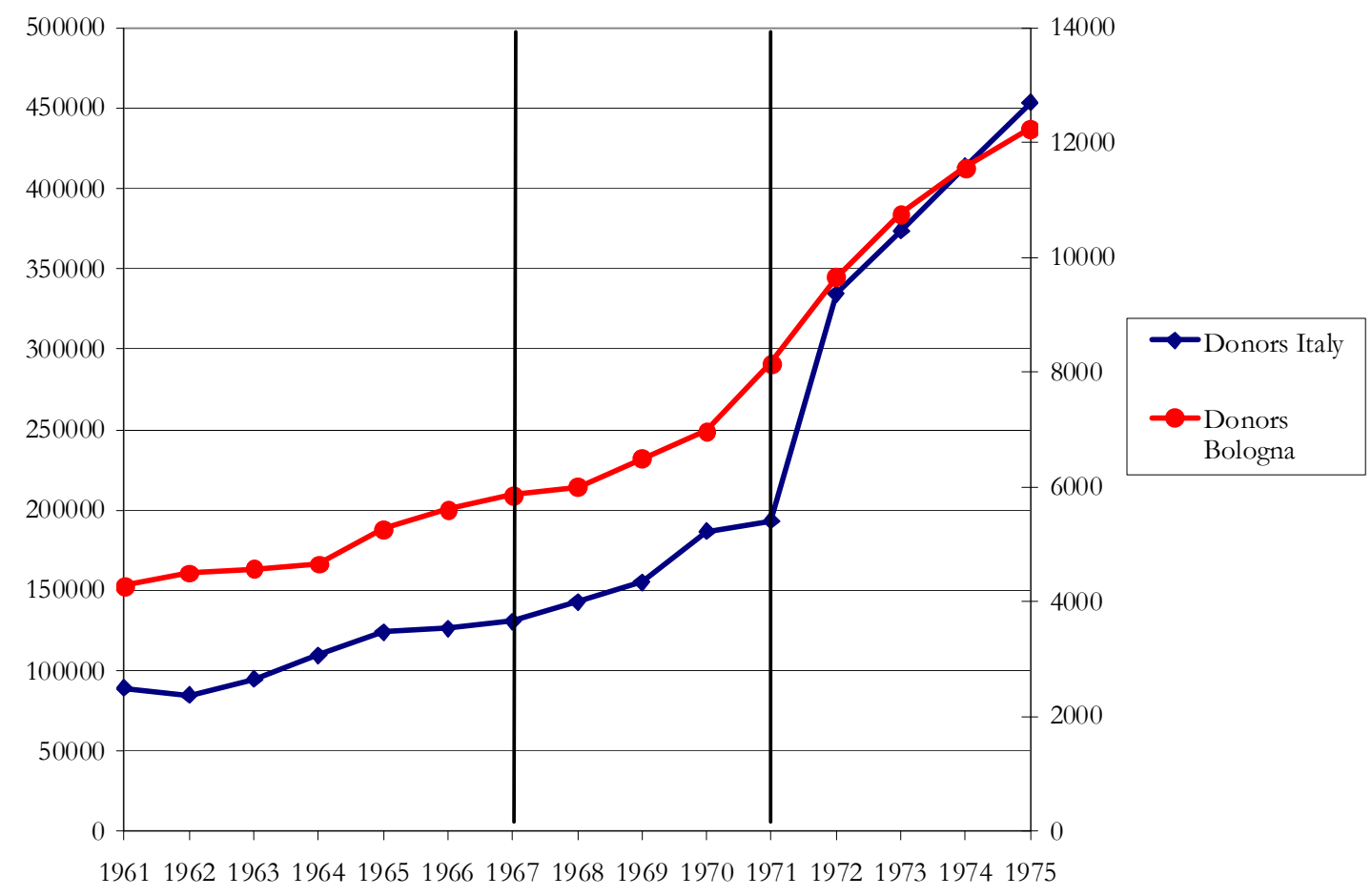

Figure 10: Number of AVIS members in Italy and in Bologna (a major city in the Center-North of Italy), years 1961-1975. The vertical lines indicate the year the Law introducing the paid leave of absence for donors was passed (1967), and the year when AVIS started a national media campaign to inform donors about its activities (1971). 